\title{
Helsingin moninaiset karjalaiset muistin paikat
}

\author{
Anssi Neuvonen, Maria Lähteenmäki, Oona Ilmolahti \& Sinikka Selin
}

L ukuisissa humanistisissa tutkimuksissa on korostettu runsaan kymmenen vuoden ajan Karjaloiden ja karjalaisuuksien erityisyyksiä (mm. Fingerroos \& Loipponen 2007; Suutari 2013) ja moniäänisyyttä (Lähteenmäki \& Karhu 2012). Monet Karjalat ovat kohdanneet toisensa myös Suomen pääkaupungissa, missä karjalaisuutta on rakennettu aktiivisesti osaksi kaupunkitilaa. Helsinki on rakennettu jo lähtökohtaisesti muuttoliikkeiden, Suomen kansallisten symbolien ja monikulttuurisuuden keskukseksi - kohtaamispaikaksi, jonka julkiseen tilaan pystytetyt maamerkit ja rakennukset kiinnittyvät hyvinkin erilaisten yhteisöjen identiteettikertomuksiin. Kaupunkitila antaa vihjeitä siitä, keitä olemme, keitä emme ole tai keitä voisimme olla. Kaupungit ovat monipaikkaisen muistin keskuksia, joiden ajallinen ja kulttuurinen kerrostuneisuus muodostuu myös sellaisista elementeistä, jotka viittaavat muualla sijaitseviin paikkoihin ja muualta kaupunkiin muuttaneisiin ihmisiin ja yhteisöihin. $\mathrm{Ne}$ johdattelevat kysymään, minkä muotoista Helsingin julkisessa tilassa havaittava karjalaisuus on.

Ennen toista maailmansotaa Karjala näkyi Helsingin julkisessa tilassa erityisesti kalevalaisaiheisina patsaina ja kadunniminä. Toisen maailmansodan jälkeen kaipuu salaperäisenä koettuun rajantakaiseen Karjalaan vaihtui Neuvostoliitolle luovutetun Viipurin läänin muistelemiseen. Karjalan siirtoväen evakkonostalgiasta ja kadonneesta suomalaisesta Karjalasta tuli kaikkien tuntema osa kansallista kertomusta, jota elettiin, muistettiin ja muisteltiin uusilla asuinsijoilla - myös Helsingissä, josta muodostui siirtoväen keskeisin asuinkeskittymä (Paukkunen 1989; 1997). Samalla varhaisemmat, karelianismin myötä kaupunkitiloihin rakennetut julkiset Karjala-aiheiset monumentit alkoivat saada rinnalleen luovutettuun Karjalaan viittaavia muistomerkkejä, ja karjalaisuuden hahmottuminen osana kaupunkiympäristöjä muuttui aikaisempaa kerroksellisemmaksi ja moniselitteisemmäksi. Siinä missä 1800- ja 1900-lukujen taitteen kalevalais-karjalainen ${ }^{1}$ romantiikka oli usein kohdistunut yksittäisiin merkkihenkilöihin ja -hahmoihin, siirtokarjalaisuudelle muodostuivat ominaisiksi evakkokokemusten kautta rakentuvat kollektiiviset kärsimys- ja selviytymisnarratiivit. Toisen maailmansodan jälkeen Helsingin yhdeksi ominaispiirteeksi tuli myös se, että pitää keskeisenä ilmiönä. (Sihvo 1969.) 
kaupungista muodostui merkittävä keskus valtavirtaisesta agraarikarjalaisuudesta poikenneelle viipurilaisuudelle ${ }^{2}$.

Menetyskertomuksiin ja muistoihin perustuva siirtokarjalaisuus on eri puolilla Helsinkiä asettunut rinnakkain näkyvän mutta kiinnostavalla tavalla implisiittisen karjalaisuuden kanssa, joka on havaittavissa esimerkiksi julkisissa monumenteissa, yritysten ja seurojen toiminnassa sekä niiden käyttämissä nimissä, väreissä ja symboliikassa. Karjalaisuus hahmottuu nyky-Helsingin kaupunkitilassa muistin paikkoina, jotka viittaavat valikoidusti Karjalan kerrokselliseen menneisyyteen ja ilmentävät erilaisia karjalaisuuskäsityksiä urbaanissa ympäristössä. Samalla kaupunkikarjalaiset muistin paikat neuvottelevat karjalaisuuden kytkeytymisestä osaksi yleissuomalaisuutta ja monikulttuurista helsinkiläisyyttä.

\section{Tutkimuksellinen kehys}

Artikkelimme $^{3}$ tapaustutkimuksena on kolme Helsingin kaupunkitilaan sijoittuvaa muistin paikkaa: Larin Parasken patsas, viipurilaistaloistaan tunnettu Kuusitie lähiympäristöineen Meilahden kaupunginosassa sekä Karjalatalo. Tutkimuskysymyksiämme ovat, miten kyseiset paikat ovat kytkeytyneet Karjalaan ja rakentaneet karjalaisuutta Helsingin kaupunkitilassa sekä millaisia paikallistoimijoiden välisiä neuvotteluja kunkin muistin paikan taustalta on mahdollisesti löydettävissä.

Ensimmäinen kohteistamme on Hesperian puiston eteläosassa olevassa Hakasalmen puistossa sijaitseva Larin Parasken muistomerkki, joka on pystytetty vuonna 1949 keskeiselle paikalle Mannerheimintien varrelle. Pohjois-Inkerissä syntynyttä ja myöhemmin Karjalankannaksella asunutta runonlaulajaa esittävä, Alpo Sailon suunnittelema veistos on ainoa naisen näköispatsas Helsingissä. Patsas edustaa runonlauluperinnettä ja kalevalaista kulttuuria, jotka on tulkittu vahvasti karjalaisiksi ilmiöiksi. Sen lisäksi, että Paraskea esittävä taideteos erottuu naisfiguurina Helsingin ydinkeskustaan pystytettyjen näköispatsaiden suurmieskuvastosta, kiinnostavaa on Parasken henkilötausta, joka luo muistomerkin ympärille valtionrajat ylittäviä merkitysten kerrostumia.

Toinen kohteistamme on karjalaisuuden hahmottuminen Meilahden kaupunginosassa. Toisen maailmansodan jälkeen viipurilaista siirtoväkeä muutti runsaasti alueelle - etenkin Kuusitielle rakennettuihin korkeisiin kerrostaloihin. Siirtymä on mahdollistanut uudenlaisen perinteen muotoutumisen ja suomalaisen Viipurin historian päätymisen osaksi helsinkiläisten paikallisidentiteettiä (Helsingin Uutiset 30.4.2020). Kolmantena kohteenamme on Käpylän kaupunginosassa sijaitseva Karjalatalo. Vuonna 1974 valmistunut, arkkitehti Into Pyykön suunnittelema rakennus on sittemmin toiminut erilaisten karjalaisyhdistysten kokoontumispaikkana ja erityisesti luovutetun Karjalan muistia rakentavana ja ylläpitävänä keskuksena.

2 Viipurilaisuus on tässä artikkelissa ymmärretty osaksi karjalaisuutta, sillä Viipurin ja viipurilaisuuden symbolista merkitystä osana (siirto)karjalaisuutta voi pitää keskeisenä. Tästä kertoo esimerkiksi se, että useiden luovutettua Karjalaa ja siirtokarjalaisuutta käsittelevien teosten kanteen on valittu Viipuri-aiheinen kuva (mm. Kanervo, Kivistö \& Kleemola 2018).

3 Artikkeli on osa Urbaani karjalaisuus -tutkimushanketta, jota rahoittaa Karjalaisen Kulttuurin Edistämissäätiö. Hankkeen johtaja on professori Maria Lähteenmäki ja tutkijoina FT Oona IImolahti, FM Anssi Neuvonen ja FT Sinikka Selin Karjalan tutkimuslaitoksesta Itä-Suomen yliopistosta. 


\section{Kartta 1. Tutkimuskohteiden sijainnit Helsingissä}

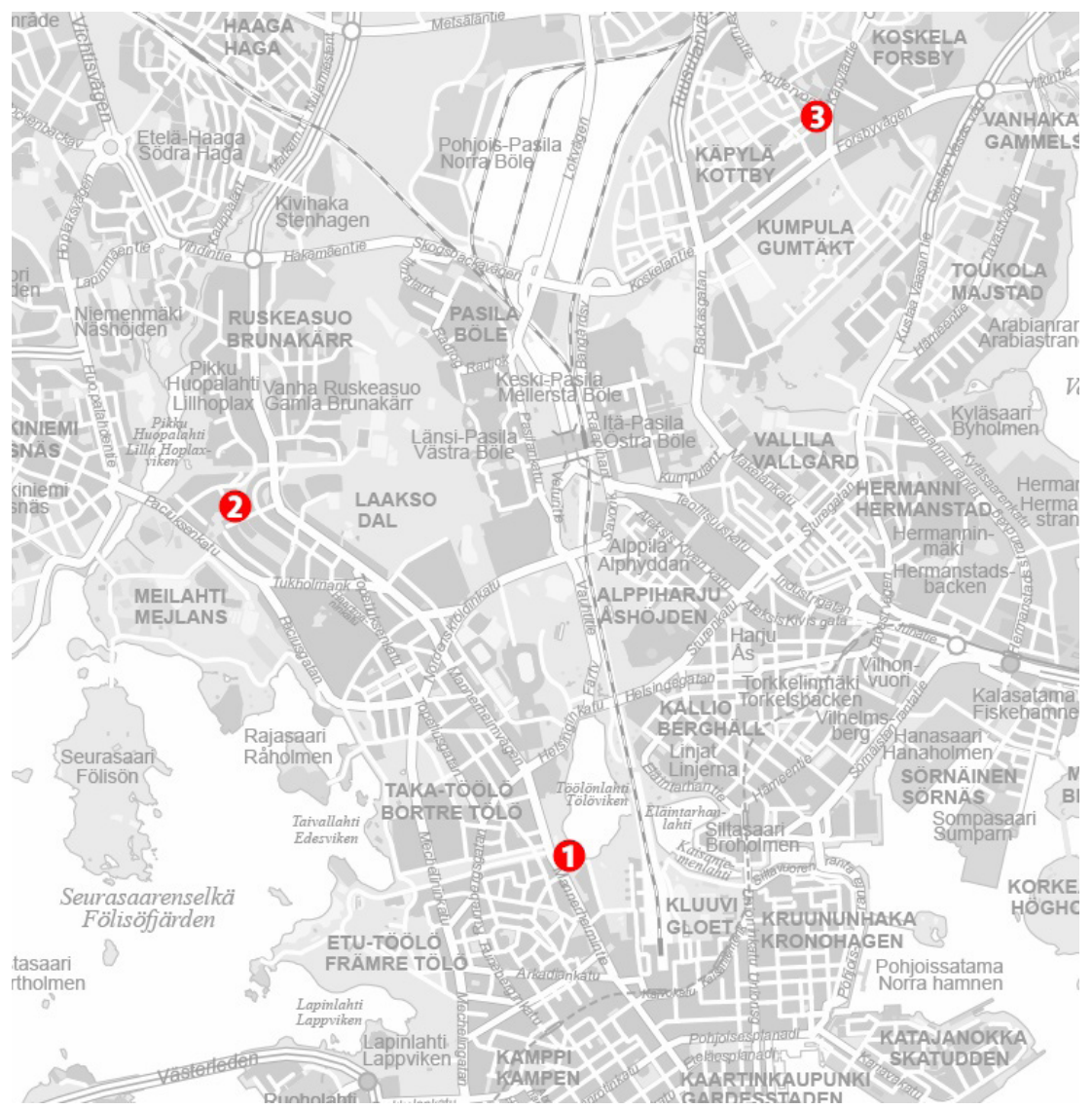

1. Larin Parasken patsas. 2. Meilahden viipurilaistalot. 3. Karjalatalo. Karttapohja: Helsingin kaupungin karttapalvelu.

Helsingin julkisesta tilasta on löydettävissä ainakin 270 viittausta Karjalaan paitsi muistomerkeissä myös rakennuksissa, toiminimissä ja kadunnimissä. ${ }^{4}$ Kolme tapaustutkimustamme ovat valikoituneet tarkemman analysoinnin kohteeksi syystä, että tehdessämme taustatutkimuksia koko Helsingin alueen Karjala-viittauksista juuri kyseiset kohteet nousivat esiin erityisen tärkeinä ja miltei ohittamattomina karjalaisuuden pilkahduksina kaupungissa. Rajauksellista valintaa tukivat kohteiden sijainnit kantakaupungissa sekä niiden esiintymistiheys ja painoarvo paikallishistoriallisissa keskusteluissa.

Pääasiallisina tutkimusaineistoinamme olemme hyödyntäneet kuhunkin tutkimuskohteeseemme liittyviä historiallisia lähteitä: kaupunginhallituksen asiakirjoja Helsingin kaupunginarkistossa, yhdistysten arkistoja Kansallisarkistossa, rakennusten piirustuksia, lehtikirjoituksia, muistitietoa sekä valokuvia ja audiovisuaalisia tallenteita. Lähteiden analysointimenetelmänä on toiminut lähiluku, joka tarkoittaa tulkintaan ja ymmärrykseen tähtäävää empiiristä menetelmää. Lähiluku on useiden eri lukukertojen myötä syntyvä tiedollinen prosessi, jonka aikana tutkimusaineistojen osat ja niiden väliset suhteet punoutuvat merkitysten verkostoksi samalla kun lähteet, tutkimuskirjallisuus ja johtopäätelmät kumuloituvat tieteellisen tekstin muotoon (mm. Brummett 2019; Pöysä 2010, 331-344). Doreen

$4 \quad$ Helsingistä löytyy Karjala-viittauksia ainakin kuudessa julkisessa muistomerkissä, 17:ssä rakennuksessa, 17:ssä kadunja paikannimessä ja 230:ssa toiminimessä. Mukaan ei ole laskettu Kalevala-viittauksia. 
Massey on esittänyt, että paikkojen kotikutoinen erityislaatuisuus on osittain väistynyt globaalien kulttuurien vaikutuksesta, jolloin paikat ovat muuttuneet keskenään samankaltaisiksi ja kadottaneet sisäistä yhtenäisyyttään (Massey 2008, 134). Rajaseudun kulttuuriin ja historiaan kytkeytyvät kaupunkikarjalaiset muistin paikat ehdottavat Helsingin "kotikutoisuuden" rakentuneen maantieteellisesti toisaalle viittaavista aineksista ja yhteydestä kansalliseen historiakertomukseen. Vuosikymmenten ajan pääkaupungin julkisessa tilassa säilytetyt kaupunkikarjalaiset muistin paikat edustavat pysyvyyttä, mutta niiden lähiympäristöt, asemat ja niihin liittyvät keskustelut ovat muuttuneet ajassa. Näin ollen olemme hyödyntäneet tutkimuksessamme historiallisten lähteiden ohella kaupunkisuunnistusta, joka on tehty Helsingissä kesäkuussa 2021. Kaupunkisuunnistus tarkoittaa kävellen toteutettavaa osallistuvan havainnoinnin menetelmää, jonka yhteydessä jalkaudutaan kaupunkitilaan ja havainnoidaan tutkimuskohteita niiden sen hetkisessä olomuodossaan ja ympäristössään (ks. Lähteenmäki 2012; Saaranen-Kauppinen \& Puusniekka 2006).

Helsingin julkisen tilan ja kaupunkikarjalaisten muistin paikkojen tarkastelu kytkeytyvät tässä yhteydessä kysymykseen 2000-luvun karjalaisuuksista ja niiden suhteesta monikollisia Karjaloita koskeviin historiallisiin mielikuviin ja Helsingin urbaaniin identiteettiin. Helsinki on vähintään parinsadan vuoden ajan ollut erilaisten vähemmistöjen ja alueellisten identiteettien kohtaamisareena, ja myös karjalaisuus on näkynyt kaupungin katukuvassa pitkään. ${ }^{5}$ Ei ole kuitenkaan yksiselitteistä, mitä karjalaisuudeksi on kulloinkin ymmärretty ja keitä karjalaisiksi on kutsuttu: Karjalan asema osana suomalaisen kansakunnan kertomusta on vaihdellut poliittisen kontekstin mukaisesti ajassa. Karjalaisuus on kompleksinen, kerrostunut ja kontekstisidonnaisesti muuntuva käsite, jota on tuotettu ainakin alueellisista, kansallisista ja kielellisistä lähtökohdista käsin (esim. Knuuttila ja Suutari 2013, 9-18).

Helsingissä karjalaisuus on määrittynyt muun muassa lähtömaakunnan, kulttuuriperinnön ja kielen kautta. Keskeisiä tekijöitä ilmiön rakentumisessa ovat olleet eri puolilta Karjalaa Helsinkiin suuntautuneet eriaikaiset muuttoliikkeet, joista osa on ollut valtionrajoja ylittäviä. Toisen maailmansodan jälkeen Suomessa tuotettu karjalaisuuskuvasto on keskittynyt evakoihin (esim. Ilmolahti et al. 2021), mutta Helsinkiin on muuttanut Karjalan siirtoväen ohella väestöä Suomen Etelä- ja Pohjois-Karjalasta sekä Venäjän Karjalasta, minkä vuoksi pääkaupungissa on rakennettu karjalaisuutta monenlaisin painotuksin. ${ }^{6}$ Toisaalta karjalaisuuteen on totuttu liittämään evakkoudesta kumpuavan kokemushistorian ohella kotiseudun luonto ja maaperä (Ilmolahti \& Lähteenmäki 2021), mikä luo yhdistäviä tekijöitä erilaisten karjalaisuusartikulaatioiden välille. Oma lukunsa on Helsingin keskeinen rooli Viipurista

5 Varhaisimpia kollektiivisia karjalaisomakuvia pääkaupungissa tuottaneita yhteisöjä olivat osakunnat. Wiipurilainen Osakunta oli aloittanut toimintansa jo 1600-luvulla Turussa, ja yliopiston siirryttyä Helsinkiin Wiipurilaisesta Osakunnasta erkaantui 1830-luvulla Savo-Karjalainen Osakunta, josta irtautui edelleen 1900-luvun alussa Karjalainen Osakunta.

6 Vienan Karjalan sivistyksellisten olojen kehittämistä varten perustettu Vienan Karjalaisten Liitto rekisteröitiin Helsinkiin 1906. Yhdistys vaihtoi nimensä Karjalan Sivistysseuraksi 1917. Venäjän Karjalasta Suomeen vuosina 1918-1922 tulleesta 11000 pakolaisesta noin 6000 jäi Suomeen pysyvästi (Hämynen 2013, 184). Maailmansotien välisenä aikana Helsinkiin muutettiin runsaasti Viipurin läänistä; vuosien 1926-1939 muuttotase Viipurin läänistä Helsinkiin oli lähes 19000 henkilöä (Palomäki 2011, 134). Kyseisen muuttoliikkeen seurauksena Helsingin keskustaan perustettiin esimerkiksi Carelia-Apteekki, joka suosi Karjala-symboliikkaa tuotteissaan. Toisen maailmansodan jälkeen Helsingistä tuli siirtoväen keskeinen asutuskeskus; 1940-luvun lopussa kaupunkiin oli hakeutunut noin 30000 evakkoa (Palomäki 2011, 21). Seuraavina vuosikymmeninä Helsinkiin perustettiin runsaasti siirtokarjalaisyhdistyksiä. Suuren maaltamuuton yhteydessä muuttovirta Itä-Suomesta Helsinkiin oli suurimmillaan 1950-luvun alusta 1970-luvun puoliväliin (Taulukko 2008. Helsingin tulo- ja lähtömuutto lääneittäin 1911-1994. Helsingin seudun aluesarjat), mikä johti pohjoiskarjalaistaustaisten kotiseutuyhdistysten perustamiseen. Neuvostoliiton hajoaminen ja sen jälkeen Venäjältä Suomeen suuntautunut muuttoliike ovat näkyneet Helsingissä muun muassa Venäjän Karjalaan kytkeytyvien yhdistysten perustamisena. 
evakuoidun väestön sijoittumisessa, ja Viipurin kaupunkihistoria näkyykin nykyisin monin tavoin Helsingissä. Karjalaisuuden esiintyminen Helsingin kaupunkitilassa on antoisa tutkimuskohde erityisesti siksi, että muuttoliikkeiden keskuksena Helsinki on toiminut eriaikaisten karjalaisuuskäsitysten risteyksenä - ovathan monet Karjalat kohdanneet siellä toisensa.

Tutkimuksemme teoreettisena lähtökohtana on muistin politiikka (Davydova-Minguet 2015; Grönholm \& Sivula 2010; Hodgkin \& Radstone 2003), jolla tarkoitetaan menneisyyden merkityksellistämistä tietyin tarkoitusperin. Maurice Halbwachsia mukaillen yhteisö määrittää puitteet yksilölliselle muistamiselle: yksilöiden muistaminen on aina sosiaalisesti määrittynyttä (Halbwachs 1992, 37-38). Yksilöllinen muistaminen on kytköksissä kollektiiviseen muistiin, joka on yhteisön muodostama valikoima kulttuurista tietoa $(\mathrm{mm}$. Assmann 1995, 126) pitäen sisällään ajallisia kerrostumia, paikkoja ja tapoja esittää menneisyyttä. Kaupunkitilassa kollektiivisen muistamisen ilmauksia ovat esimerkiksi muistomerkit, joita Frank Ankersmit on kuvaillut tienviitoiksi historiaan (Ankersmit 1999, 94-95). Lähteenmäen mukaan muistomerkit ja rakennukset ovat ikkunoita paitsi yhteisöjen sisäisiin ja ulkoisiin poliittisiin valtakamppailuihin, -suhteisiin ja hierarkioihin, myös kunkin historiallisen ajan sosiaalis-kulttuurisiin arvoihin, asenteisiin ja tunnemaailmoihin (Lähteenmäki 2018, 11). Kollektiivisen muistin rakentumisessa keskeistä on maamerkkien ja rakennusten viestimä kulttuurinen tieto, jota ei tule ajatella pysäytettynä kulttuuristen merkitysten ensyklopediana vaan menneisyyttä koskevien tietojen jäsentämisenä: kollektiivisen muistamisen prosessinomaisuutta ja siihen kytkeytyvää valtaa ja toimijuutta on korostanut esimerkiksi kulttuurihistorioitsija Anna Green (Green 2008, 88, 106).

Analyysimme kohdistuu kaupunkitilassa havaittaviin karjalaisuuden representaatioihin hyödyntämällä muistin paikat -käsitettä. Kaupunkitila on täynnä muistin paikkoja, joita Pierre Nora on jaotellut topografisiin (arkistot, kirjastot ja museot), monumentaalisiin (hautausmaat ja rakennukset), symbolisiin (seremoniat, pyhiinvaellukset, vuosijuhlat ja embleemit) ja funktionaalisiin (opaskirjaset, omaelämäkerrat, yhdistykset) muistin paikkoihin (Nora 1978, 401). Muistin paikoilla tarkoitetaan sellaisia menneisyyttä koskevien merkitysten kristallisoitumisia, jotka on irrotettu "alkuperäisestä" ympäristöstään ja jotka siten luovat uudenlaisen ja osin problemaattisenkin historiallisen jatkuvuuden tunnun (Lento \& Olsson 2013, 15; Nora 1996, 1; Åström 2013, 53). Muistin paikkoja tuotetaan rakentamalla, kirjoittamalla ja puhumalla. Niiden merkityksiä luodaan uudelleen, jolloin ne etääntyvät alkuperäisestä tarkoituksestaan ja ryhtyvät kantamaan uudempien tulkitsijoiden niihin liittämää historiallista muistia. (Fingerroos 2006, 5; Nora 1996, 6-7; Åström 2013, 53-54.)

Hahmotamme muistin paikkoja empiriamme perusteella tutkimuskohteina, jotka ovat fyysiseen kaupunkitilaan sijoittumisensa ohella sosiaalisesti tuotettuja konstruktioita. Tarkastelemamme julkiset muistin paikat ovat sosiaalisen rakentumisensa vuoksi vahvasti aikasidonnaisia. Ne eivät rakennu enää samanlaisina kuin syntykontekstissaan, vaan niiden merkitys ja niistä esitetyt tulkinnat ovat muuttuneet eri aikakausina. Taidehistorioitsija Jennifer Wingate onkin huomauttanut, että monumentit voivat olla kuolleita, mykkiä, unohdettuja, hylättyjä tai eläviä riippuen niiden kulloinkin nauttimasta huomiosta ja arvonannosta (Wingate 2013, 191). Muistin paikkojen muotoutumisen kannalta huomionarvoista on myös se, että julkiset monumentit ovat voineet syntyä tietoisesti rakentamalla tai tahattomasti (Riegl 1982). Karjalaan ja sen historiaan viittaavat nimet ja symbolit indikoivat karjalaisia muistin paikkoja. Niiden kytkeytyminen karjalaisuuteen on helppoa havaita yleisimmin tunnettujen symbolien, kuten Karjalatalon ja Karjalan vaakunan kohdalla. Vastaavasti vähemmän tunnetut 
indikaattorit, kuten keskiverto-ohikulkijalle tuntemattomaksi jäävä naisrunonlaulajapatsas Mannerheimintien varrella ja karjalaislähtöisten urheiluseurojen punamustat värit, voivat vaatia tarkempaa taustatietoa tullakseen ymmärretyiksi ja tulkituiksi karjalaisuuden viitekehyksessä.

\section{Karjalais-suomalainen Larin Paraske}

Helsingin henkilöpatsasgalleriassa kulttuurin ja taiteen henkilöt ovat olleet alusta alkaen nostettuina valtiollisten henkilöiden rinnalle. Pääkaupungin ensimmäinen suuri julkinen monumentti, runoilija J. L. Runebergin patsas, paljastettiin Esplanadin puistokadulla valtavan yleisöjoukon ympäröimänä 6.5.1885 (mm. Wiipurin Sanomat 9.5.1885, 1-2). Vienan Karjalan retkeilijän ja Kalevalan syntyyn keskeisimmin vaikuttaneen Elias Lönnrotin muistomerkki pystytettiin Kamppiin Lönnrotinkadun varrelle lokakuussa 1902 (Päivälehti 18.10.1902, 2). Patsasinnostuksessa oli kyse kansainvälisestä virtauksesta: 1800- ja 1900-lukujen taitteessa länsimaissa pystytettiin paljon monumentteja kaupunkien julkisiin tiloihin. Tätä kansallisten identiteettien rakentamiseen keskeisesti liittynyttä muistomerkkitoimintaa on kutsuttu statuomaniaksi (Agulhon 1978) ja monumentomaniaksi (Berggren 1999). Eric Hobsbawm pitää 1800- ja 1900-lukujen taitteessa tapahtunutta julkisten monumenttien massatuottamista yhtenä keskeisimmistä tekijöistä perinteiden keksimisessä kansallisvaltioille (Hobsbawm 2012). June Hargrove on kirjoittanut julkisten veistosten kategoriasta, jossa alueelliset muistamisen ilmaukset toimivat kollektiivista identiteettiä kokoonpanevina elementteinä ja integroivat samalla paikallisuutta osaksi kansakunnan historiakertomusta (Hargrove 2005, 59).

Helsingin Hesperian puistossa julkistettiin 3.12.1949 patsas, joka esittää runonlaulaja Larin Paraskea (1833-1904). Muistomerkin luovutti Keskusosuusliike Hankkijan pääjohtaja Väinö Pessi, ja sen vastaanotti Helsingin kaupunginjohtaja Eero Rydman. Paikalla tilaisuudessa oli edustajia Kalevalaisten Naisten Liitosta ja Etelä-Karjalan Nuorisoseurasta. Wiipurilaisen Osakunnan kuoro esiintyi. (Finlandia-katsaus 119, 1949; Helsingin Sanomat 4.12.1949, 5).

Larin Parasken päätyminen kalevalaista runonlauluperinnettä symboloivaksi henkilöksi ei ollut suoraviivainen prosessi. Ortodoksiseen perheeseen Pohjois-Inkerin Lempaalan Mäkienkylässä syntynyt Paraske Mikitantytär avioitui 20-vuotiaana Itä-Kannaksen Sakkolan (sittemmin Metsäpirtin) Vaskelaan, Larilan (Larin) taloon (Timonen 1997). Parasken kohdalla on yleensä nostettu esiin hänen poikkeuksellinen muistinsa runonlaulajana ja toisaalta hänen elämässään vallinnut aineellinen niukkuus (Suomen Kuvalehti 23.2.1935, 308-309). Paraskelta kerättiin harvinaisen suuri määrä runoaineistoa, yhteensä noin 1200 runoa (noin 32000 säettä), 1750 sanalaskua, 336 arvoitusta ja itkuvirsiä (Sihvo 2005, 182). Hän kohosi jo elinaikanaan tieteilijöiden ja taiteilijoiden innoittajaksi ja julkisuuden henkilöksi, joka kuitenkin tarvitsi yhteistyökumppaneidensa taloudellista apua huolehtiessaan leskeksi jääneenä talostaan ja perheestään (Timonen 1981, 150-154).

Paraske haluttiin 1800-luvun lopulla pukea ja kokea viimeiseksi runonlaulajaksi ja "muinaisuuden ilmentymäksi". Muotokuvissa, kuten Albert Edelfeltin maalauksessa vuodelta 1893, Paraskella on yllään yhteistyökumppaninsa Adolf Neoviuksen hankkima esiintymisasu, johon kuului itäkannakselainen naisen sarkaviitta sekä harakka, ortodoksivaimon päähine 
(Sihvo 2005, 190-193).7 Parasken kuoleman jälkeen 1900-luvun alussa Neovius alkoi puuhata hänelle hautamuistomerkkiä Karjalankannakselle (SKS:n kokouspöytäkirja 3.5.1911). Lopulta Suomalaisen Kirjallisuuden Seura ja Etelä-Karjalan Nuorisoseura pystyttivät hautamuistomerkin Raudun Palkealaan seitsemän vuotta Parasken kuoleman jälkeen elokuussa 1911 (mm. Viipurin Sanomat 7.8.1911, 1-2). ${ }^{8}$

Larin Parasken patsaan synty liittyy 1900-luvun alun kansallisromanttisiin suomalaisuusvirtauksiin, joiden taustalla Kalevala ja karelianismi olivat keskeisiä vaikuttimia. Kun Parasken syntymästä oli vuonna 1933 kulunut sata vuotta, hänestä kirjoitettiin runsaasti muistokirjoituksia sanomalehdissä (mm. Helsingin Sanomat 28.12.1933, 7). Hänen nimensä oli tuoreessa muistissa valmisteltaessa Kalevalan 100-vuotisjuhlaa, jota vietettiin Helsingissä vuonna 1935. Juhlavuosi sai aikaan julkisen keskustelun, jossa määriteltiin Kalevalan ja suomalaisuuden keskeisimpiä symboleja, hahmoja ja henkilöitä - joista monet kytkeytyivät Karjalaan tai olivat karjalaisia. Pääasiassa Suomen ja Venäjän Karjalasta kerätyn Kalevalan perintöä ja kansallista merkitystä ryhdyttiin 1930-luvun keskusteluissa pohtimaan uudessa kontekstissa: kalevalaista toimijuutta pyrittiin laajentamaan, ja tätä varten haluttiin luoda uudenlaisia muistomerkkejä. Kalevalaisen naistoimijuuden määritteleminen oli yksi aspekti tässä ilmiössä. Vuonna 1936 perustettiin Kalevalaisen Naisen Muistomerkkitoimikunta ${ }^{9}$ ajamaan kalevalaisen naisen muistomerkin pystyttämistä Helsinkiin. Larin Parasken noustessa esiin näissä keskusteluissa karjalaisuus ei ollut ensisijainen häneen yhdistetty nimittäjä, vaan sellaisia olivat kalevalaisuus ja suomalaisuus. Paraske nähtiin linkkinä nykyhetken ja suomalaisuuden "alkukodin" välillä. Samalla kyse näyttää olleen kansallisen naisroolimallin etsimisestä. Aikakauden keskusteluissa huomiota saivat Parasken lahjakkuuden ohella hänen henkilökohtaiset kärsimyksensä ja ulkonäkönsä, jotka nähtiin soveliaina kalevalais-suomalaisen naisihanteen ja "suomalaisen muinaisuuden" määrittelemiseen. (Ilta-Sanomat 28.2.1936, 1; Suomen Kuvalehti 23.2.1935; Uusi Aura 26.2.1939, 6; Vaasa 14.5.1934, 1.)

Karjala-myönteisessä ja kansallisromanttisessa ilmapiirissä oli tilausta Parasken muistomerkin veistäneen Alpo Sailon palavalle Kalevala-innostukselle. Hän teki Parasken näköispatsaan vuonna 1936 tarkoituksenaan sijoittaa se Kalevalataloon, eräänlaiseen "suomalaisen kulttuurin Pantheoniin", joka oli 1920-luvulla Kalevalaseuran ja myöhemmin erityisesti Sailon ajama massiivinen, lopulta toteutumatta jäänyt rakennushanke. ${ }^{10}$ (Kivelä 1985, 73; Saarinen ja Kalevalaseura 1921; Sailo 1920; Väisänen 1956, 267-268.)

Maataloustuotteita myynyt Keskusosuusliike Hankkija halusi 1940-luvun lopussa pystyttää Larin Parasken patsaan pääkonttorinsa edustalle Arkadianaukiolle (nyk. Paasikivenaukio),

Karjalaisia runonlaulajia puettiin kaupunkilaissivistyneistön toimesta laajemminkin. Esimerkiksi Matjoi Plattonen oli vaatetettu Kansallismuseon muinaiskarjalaiseen asuun hänen esiintyessään Norjan kuninkaalle 1920-luvulla (Helsingin Sanomien viikkoliite 15.7.1928, 2). pystyttivät 1990-luvun alussa Rautuun (ven. Sosnovo) uuden hautakiven, johon kiinnitetyn reliefin on suunnitellut Nina Sailo, Alpo Sailon puoliso. (Suomen Kuvalehti 28.8.1992, 11.) ja -taiteilijoita (IIta-Sanomat 28.2.1936, 1). Toimikunnan varainkeruu epäonnistui. Sen toimintaa jatkoivat Kalevalaisten Naisten Liitto ja Kalevala Koru, joka ryhtyi myymään muinaiskorumallien mukaisia koruja (Piela 2001). KNL ja Kalevala Koru hankkivat vuonna 1945 kalevalaisen naisen patsaakseen Emil Halosen tekemän Louhi-patsaan (Helsingin kalevalaiset naiset ry).

10 Kalastajatorpan kallioille Munkkiniemeen 1920-luvulla rakennettavaksi suunniteltuun Kalevalataloon hahmoteltiin kuuluvan muun muassa suuri sali, kirjasto, taidekokoelma, tutkimuskeskus ja asuntoja, ruokala, kalevalaisten hahmojen ja merkkihenkilöiden patsaita, freskoja sekä tuonela eli kansallisaatteen hengessä kaikkein ansioituneimpien merkki(mies)henkilöiden hautakrypta. (Saarinen ja Kalevalaseura 1921.) 
mutta kaupunginhallitus ohjasi patsaan sivummalle Hesperian puistoon vedoten liikenteen läheisyyteen. ${ }^{11}$ (Helsingin kaupunginhallituksen pöytäkirjat 13.1.1949 ja 10.2.1949, Kaupunginhallituksen pöytäkirjat 1949 Ca:19, Hka; Helsingin kaupunginhallituksen pöytäkirjojen liitteet §101, Kaupunginhallituksen pöytäkirjain liitteet, tammikuu 1949 Cb:130, Hka.) Myös Parasken itäisyyttä ja oletettua venäläisyyttä on voitu vierastaa sodanjälkeisessä yhteiskunnallisessa ilmapiirissä.

Hankkijan kytkökset yhteiskunnan agraarisiin kerrostumiin näkyvät siinä, että muistomerkin jalustaan kaiverretussa tekstissä Paraske nimetään kansanrunouden ja -tietouden taitajaksi ja tallentajaksi sekä suomalaiseksi talonpoikaisnaiseksi. Hankkijalla oli kytkös myös karjalaisuuteen, sillä heidän pääjohtajansa, Karjalankannakselta kotoisin ollut Väinö Pessi tunnettiin aktiivisena karjalais-kalevalaisten hankkeiden edistäjänä (Karjalan Heimo 9-10/1970, 132). Parasken muistomerkin jalustan tekstistä, joka kaiverrettiin toisen maailmansodan jälkeisessä ilmapiirissä, ei kuitenkaan löydy viittausta Karjalaan tai karjalaisuuteen. Patsaan jalustan takasivulle kaiverrettiin Hankkijan nimi, mutta muistomerkkiä esittävän henkilön ja veistoksen suunnitelleen kuvanveistäjän nimiä taideteoksesta ei voinut lukea vielä pitkään aikaan.

Myöhempinä vuosikymmeninä Larin Parasken patsaasta on käyty vilkasta keskustelua. ${ }^{12}$ Laajasti muistomerkki nousi paikalliskeskusteluihin 1980-luvun alussa, kun Karjalan Liitto halusi siirtää taideteoksen Karjalatalonsa edustalle Käpylään Parasken syntymän ja Kalevalan 150-vuotispäivien lähestyessä. Patsaan sijaintia kommentoitiin sanomalehdissä myös Helsingin ulkopuolelta, mikä antaa ymmärtää, että pääkaupungin julkinen tila on kriittisen arvioinnin kohde myös valtakunnallisissa kehyksissä. Kaupungin museot, virastot ja lautakunnat esittivät omia näkemyksiään patsaan mahdollisesta siirtämisestä. (Helsingin Sanomat 24.8.1981, 13; 30.8.1981, 16 ja 19.6.1987, 7.) Muistomerkki pysyi Hakasalmen puistossa.

Suomalaisen talonpoikaisuuden symboliksi Hankkijan nimeämä Larin Paraske patsaineen oli 1980-luvulle tullessa noussut siirtokarjalaisuuden symboliksi, sillä useat evakkotaustaiset yhteisöt olivat alkaneet tehdä muistin paikalle vierailuja (MV/JJ/5596/6/JÄR/56). Larin Parasken syntymän 150-vuotispäivänä 27.12.1983 patsaalla pidettiin muistotilaisuus, jonka järjestäjiä olivat Karjalan Liitto, Rautu-Seura, Metsäpirtti-Kerho ja Sakkola-Seura (Etelä-Suomen Sanomat 5.2.1984, 13). Patsaan omaksensa ottaneet siirtokarjalaistoimijat ovat olleet sivuosassa patsaan pystyttämiseen ja mahdolliseen siirtoon liittyvissä neuvotteluissa.

Useat eri yhteisöt ovat halunneet esitellä Larin Paraskea kollektiivisena symbolinaan. Paraske asui pisimmän aikaa elämästään Karjalankannaksella, mistä johtuen häntä on pidetty karjalaisena (esim. Suomen Kuvalehti 31.8.1979, 66) ja yhtenä Karjalan merkittävimmistä

Hankkija ei tyytynyt Helsingin kaupunginhallituksen ensimmäiseen paikkaehdotukseen, vaan pyysi muistomerkin sijoittamista omasta mielestään näkyvämmälle paikalle Hesperian puistossa ja lähemmäksi Mannerheimintietä, minne patsas lopulta pystytettiin (Helsingin kaupunginhallituksen pöytäkirjojen liitteet $§ 330$, Kaupunginhallituksen pöytäkirjain liitteet, helmikuu 1949 Cb:131, Hka). tellessään Arcus-nimimerkin yleisönosastokirjoitusta, jossa muistomerkin uudeksi sijainniksi oli ehdotettu Sibeliuksen puistoa tai Seurasaarta. Serp kertoi usein kuulleensa raitiovaunumatkustajien laskeneen leikkiä "mummuparan" asennosta ja kummastelleen, ketä patsas esittää. Hän myös arveli, että jos patsas on asetettu paikalleen siksi, että kansa muistaisi suuria kalevalaisia perinteitään, niin siinä oli erehdytty. Pakinoitsija patisteli kaupunginjohtaja Lauri Ahoa tarttumaan Arcuksen ehdotuksiin Paraske-muistomerkin uusista sijainneista. (Helsingin Sanomat 13.7.1958, 6). Toisaalta muistomerkin on myöhempinä vuosikymmeninä koettu olevan helposti lähestyttävä verrattuna esimerkiksi korkealle alustalle asetettuun Mannerheimin patsaaseen (Helsingin Sanomat 10.9.1997, A 17.) 


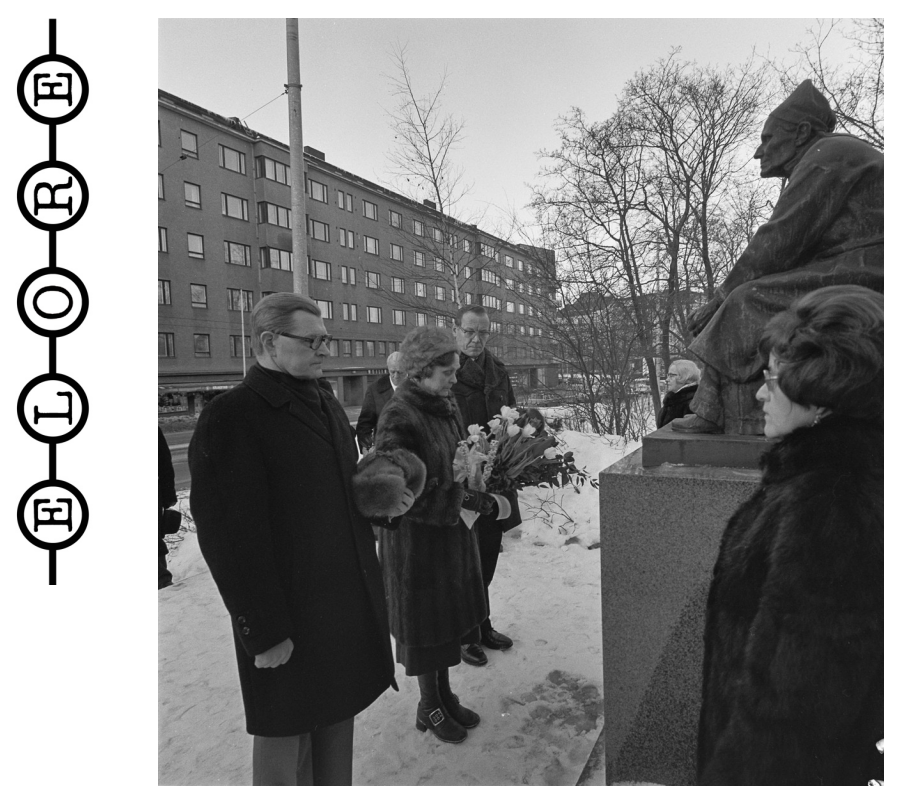

Kuva 1. Runonlaulaja Larin Parasken muistomerkki. Rautu-Seuran lähetystö kunniakäynnillä 1974 Larin Parasken muistopatsaalla Hakasalmen puistossa Helsingissä. Valokuvaaja Pekka Kyytinen. Museovirasto. runonlaulajista (esim. Suomen Sosialidemokraatti 3.1.1954, 7). Lisäksi hänet on usein asetettu karjalaisia runonlaulajia, erityisesti naispuolisia, symboloivaksi henkilöksi (esim. Helsingin Sanomat 21.4.1981, 23). Karjalaisuuden ohella Paraske on nähty aikaan ja paikkaan sidonnaisten paikallisten, alueellisten tai kansallisten motiivien mukaan ainakin suomalaisena (esim. ET 2/1999, 96-97, $99,101)$ - kuten näköispatsaan jalustaan kaiverretussa tekstissä -, sekä suomalais-karjalaisena (esim. Nuori Karjala 3/2004, 64-65), kannakselaisena (esim. Suomen Kuvalehti 23.2.1935, 339), Metsäpirtin, Raudun ja Sakkolan tyttärenä (esim. Rautulaisten lehti lokakuu 1983, 3) ja venäläisten ja priozerskilaisten maanmiehenä (ks. Nuori Karjala 3/2004, 64-65). Lisäkerrostuman on tuonut se, että häntä on pidetty inkeriläisenä (esim. Karjala 8.4.2004, 5), inkerinsuomalaisena (esim. Inkeriläisten viesti 14.4.1961, 14) ja inkeriläis-kannakselaisena (esim. Etelä-Suomen

Sanomat 3.1.2005, 22). Parasken on niin ikään katsottu kuuluneen inkeroisiin, Inkerin varhaisiin ortodoksiasukkaisiin, joita on pidetty karjalaisperäisinä (Inkeriläisten viesti 5/1998, 6; Timonen 1997). Paraske ehti asua vuosina 1891-1894 Porvoossa, ja 1970-luvun lopussa Porvoon paikallismediassa pohdittiin, tarvitseeko kaupunki Larin Parasken patsaan (Uusimaa 15.6.1979 ja 19.6.1979). ${ }^{13}$ Parasken näköispatsaan kipsioriginaali sijaitsee nykyisin Itä-Suomen yliopiston Joensuun kampuskirjaston portaikossa. Vuonna 2021 Suomen ortodoksinen kirkko kanonisoi Parasken pyhäksi ${ }^{14}$ (Suomen ortodoksinen kirkko 2021).

Kesäkuussa 2021 Larin Parasken patsas katselee yhä Mannerheimintien yli Etu-Töölön kerrostaloja. Nykyisin patsaan sivujalustassa on laatta, josta voi lukea Larin Parasken ja Alpo Sailon nimet. ${ }^{15}$ Kukkula, jolla muistomerkki sijaitsee, oli patsaan julkistamisen aikoihin aukea. Nyt patsas on kuin avohuoneessa pensaiden ja puiden keskellä, mutta sitä ympäröivä äänimaisema ja tilavaikutelma on hektinen. Historiallista naisrunonlaulajaa esittävä patsas on erityistapaus osana Helsingin (mies)näköispatsasgalleriaa ja osoitus Helsingin muistomerkkikeskustan ja suomalaisen kansallishenkilökaanonin sukupuolittuneisuudesta. Samalla Paraskea esittävä muistomerkki on vahvistanut karjalaisuuden ympärillä jo perinteisesti vahvaa feminiinisyyden auraa. Runonlaulajapatsas ei ole jäänyt ainoaksi Paraske-viittaukseksi

13 Porvoossa julkistettiin vuonna 1983 Larin Parasken ja Adolf Neoviuksen muistomedaljonki. Reliefin on suunnitellut Nina Sailo. (Rautulaisten lehti lokakuu 1983, 4-5.)

14 Ortodoksinen kirkko käyttää kanonisoidusta henkilöstä nimitystä pyhä, joka on ymmärrettävissä synonyymiksi läntisten kirkkojen pyhimykselle. Suomen ortodoksisen kirkon kanonisointiprosessissa Paraskea kuvailtiin seuraavasti: "Pyhä vanhurskas Paraske tunnetaan suomalaisen runonlaulun hahmona. Ortodoksisen Kirkon näkökulmasta hän on karjalais-suomalaisen hurskaan ortodoksisen kansanäidin esikuva, joka eli uskoaan arkipäivässä ja välitti sen seuraavalle sukupolvelle." (Piispainkokouksen 9.6.2021 pöytäkirja.)

15 Kalevalaisten Naisten Liitto kiinnitti vuonna 1995 patsaan jalustan edestä katsottuna vasemmalle sivustalle laatan (Länsi-Savo 24.4.1995, 5), johon on kaiverrettu sanat 'runonlaulaja' ja 'runosångaren', Larin Parasken nimi ja syntymäaika sekä Alpo Sailon nimi. Lisäksi KNL on vuodesta 1996 alkaen jakanut Larin Paraske -palkintoa puhutun sanan taitajille (Pirta 2/1996, 12). 
Helsingin kaupunkitilassa, sillä hänen mukaansa on nimetty vuonna 1953 käyttöön otettu Larin Parasken polku Kaarelassa (Lehikoinen 1999).

\section{Pikku Viipuri Meilahdessa}

Toisen maailmansodan aikana ja pian sen jälkeen Helsinkiin muutti runsaasti Viipurista evakuoitua väestöä. Vuonna 1946 Helsingissä oli Viipurissa vakinaisesti asunutta siirtoväkeä vajaat 9000 (2,6\%), ja vuonna 1971 kaupungissa asui hieman yli 10000 Viipurissa syntynyttä (2 \% kaupungin väkiluvusta) (Paukkunen 1989, 34). ${ }^{16}$ Helsinkiin hakeutuivat myös monet viipurilaiset yritykset ja seurat. Vanhat, karjalaiseksi mielletyn Viipurin läänin paikallisyhteisöt olivat hajonneet osana siirtoväen uudelleenasutustoimintaa, jonka toteuttamissuunnitelmissa Helsinki ja Jyväskylä oli asetettu Viipuriin ja Sortavalaan rinnastuviksi keskuksiksi. Käytännössä evakuoitua väestöä hakeutui vanhaa asuinpaikkakuntaa katsomatta rivakasti kaupunkeihin, erityisesti Helsinkiin. (Paukkunen 1989; 1997.) Siirtoväen asuttaminen ympäri Suomea ja eri puolille yksittäisiä kuntia johti siihen, ettei saarekemaisia siirtokarjalaisalueita syntynyt kovinkaan säännönmukaisesti. Pääkaupungissa kaupunkisiirtoväen keskittymiä muodostui muun muassa Meilahteen (Helsingin Sanomat 1.12.1995, B 2) ja Pirkkolaan (Palomäki 2011, 220).

Meilahteen muuttanut siirtoväki sai tutustua seudun historiaan. Vuonna 1906 Helsinkiin liitetylle Meilahdelle oli ollut ominaista kivikaupungin hivuttautuminen kohti varhaisempaa kartano-, huvila- ja puistoympäristöä. Tuolloisesta kantakaupungista katsottuna Meilahti olikin pitkään maaseutua. ${ }^{17}$ Läheiseen Seurasaareen oli perustettu kansanpuisto 1889 ja ulkomuseo 1909. Munkkiniemen huvilayhdyskunnan raitiotien valmistuminen vuonna 1914 oli lisännyt mahdollisuuksia ympärivuotiseen asumiseen Meilahdessa (Uusi Suometar 1.11.1914, 6). 1900-luvulla muodostui kaksi Meilahtea: kaupunginosan halkaisevan Paciuksenkadun ja rantaviivan välissä sijaitsivat rapistuvat huvilat (Helsingin kaupunkisuunnitteluvirasto 1977), ja samanaikaisesti uusi, uljas, urbaani asuinyhteisö nostatettiin kadun toiselle puolen.

Paikallismediassa ja -muistelussa Meilahti on esitetty etenkin viipurilaisen siirtoväen kaupunginosana (Helsingin Sanomat 1.12.1995, B 2; Helsingin Uutiset 30.4.2020). Kun toisen maailmansodan jälkeen astui sisään Meilahden Kuusitien päässä sijainneeseen sekatavarapuotiin, pystyi kuulemaan Viipurin murretta (Helsingin Sanomat 1.12.1995, B 2). Sitä saattoi kuulla myös puodin ulkopuolella ja lähitienoolla, sillä kadun varrelle rakennettuihin seitsenkerroksisiin taloihin muutti paljon viipurilaisia. Menneisyyden kerrostumat muodostivat alueella niin moniulotteisen asetelman, että silmien hieraisun voi kuvitella olleen väliin paikallaan - tämä on Helsinkiä, ei Viipuria. Kivenheiton päässä oli monikulttuurista historiaa huokuva huvila- ja puistoalue kuin heijastumana Monrepos-puistosta ja huvila-Kannaksesta, ja kerrostalon ikkunasta saattoi yhä kuulla tuttua murretta ja hiljaisena aamuna meren. Toisaalta nostalgisuuden repertuaaria rajasi Helsingissä vallinnut suuri asuntopula (Palomäki 2011, 134). Esimerkiksi Kuusitien kerrostalojen ahtaissa kaksioissa on muisteltu väliin säilytetyn

$16 \quad$ Kyseiset lukemat eivät sisällä Viipurin maalaiskunnasta evakuoitua väestöä. Vuonna 1946 Helsingissä oli Viipurin maalaiskunnassa vakinaisesti asunutta siirtoväkeä reilut 600, ja vuonna 1971 kaupungissa asui noin 1700 Viipurin maalaiskunnassa syntynyttä (Paukkunen 1989, 44).

17 Meilahden (Mejlans) kartanon ympärille rakentunut kylä tunnettiin Hindernäs-nimellä jo 1400-luvulla. Alueen puistot ja rannat muodostuivat kaupunkilaisten suosituiksi kesäretkikohteiksi 1800-luvulla. Kun Meilahden tila siirtyi kaupungin omistukseen 1871, alueen etelä- ja länsiosiin alkoi muodostua huvila-alue. (Helsingin kaupunkisuunnitteluvirasto 2014). 


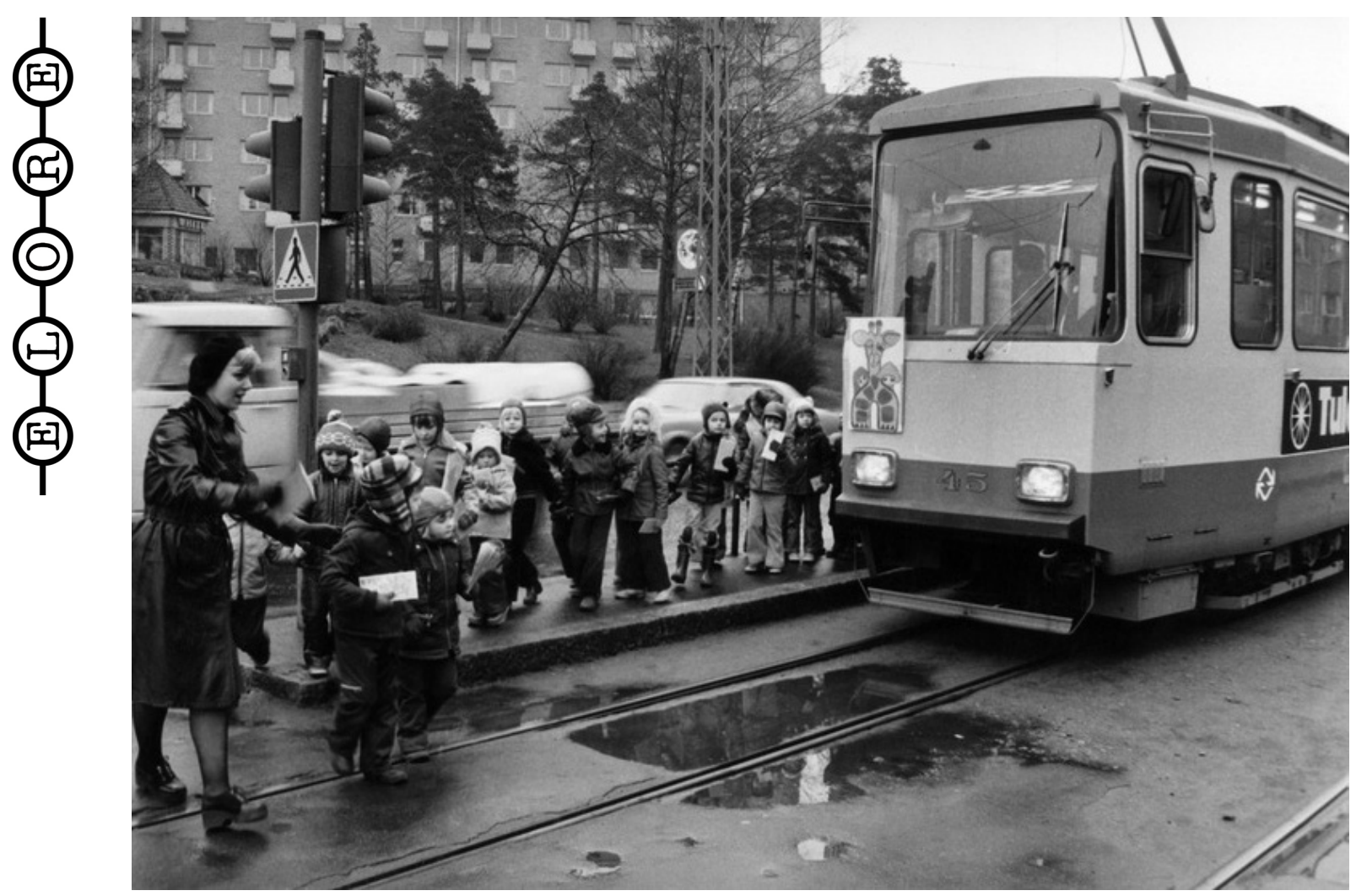

Kuva 2. Raitiotiepysäkki Helsingin Meilahdessa. Kuusitien asukkaiden yhteydet keskikaupungille ja merenrantaan ovat olleet taannoisen Viipurin tapaan liikenteellisesti mainiot, onhan kotikadulle päässyt sekä busseilla että raitiovaunuilla. Kuvassa päiväkotilapsia 1975. Valokuvaaja Unto Laitila. Helsingin kaupungin kuvakokoelmat.

lastenrattaita kylpyhuoneessa, väliin ihmetellyn kosteudesta turvonneita ovia (Helsingin Sanomat 1.12.1995, B 2).

Helsinkiläisessä paikallismuistelussa Meilahti ja siellä erityisesti Kuusitie ovat kantaneet Pikku Viipurin nimekettä (Helsingin Sanomat 1.12.1995, B 2; Helsingin Uutiset 30.4.2020; SKS KRA Helsinki - Stadini 1919. 2004). Toisaalta sanomalehdissä Pikku Viipureiksi on kutsuttu myös Pirkkolaa (esim. Uusi Suomi 27.2.1966, 14) ja Espoon Laajalahtea (esim. Uusi Suomi 4.11.1949, 5 ja 23.11.1949, 4). Yksi Helsingin jälkeen suurimmista viipurilaissiirtoväen keskuksista muodostui Lahteen (Paukkunen 1989, 34-37), missä Fellmanin kartanon entisille maille kehittynyt asutus-, yritys- ja kulttuurilaitoskeskittymä tunnetaan sekin Pikku Viipurina. Välillä kyseistä nimitystä on käytetty koko Lahden kaupungista (esim. Etelä-Suomen Sanomat 12.6.2005, 16 ja Helsingin Sanomat 25.7.1962, 8). Tarkasteltaessa Meilahtea karjalaisena kaupunginosana ja Pikku Viipurina esiin nousevat Kuusitien asuintalojen ohella pesäpallojoukkue Puna-Mustat, Naisvoimisteluseura Karjalaiset ${ }^{18}$ ja kirkonkello.

Viipurin läänin asukkaiden ensimmäisen evakkomatkan jälkeen Helsingissä perustettiin vuonna 1941 pesäpalloseura Puna-Mustat, jonka johtohenkilöihin lukeutui Viipurin, Enson, Sortavalan ja Salmin siirtoväkeä. Pesäpalloliitto oli varannut seuralle pääsarjapaikan, koska

18 Vuonna 1978 perustettu Naisvoimisteluseura Karjalaiset järjestää jumppatapahtumia Meilahdessa. Yhdistyksen verkkosivujen ja sosiaalisen median perusteella karjalaisuutta ei korosteta seuran toiminnassa. (NVS Karjalaiset 1 ja 2.) 
Enson Kisailijoiden ja Viipurin Kisa-Veikkojen toiminta oli keskeytynyt sodan vuoksi. Helsingin Sanomat piti uuden seuran päästämistä suoraan miesten pääsarjaan perusteltuna, sillä seuran pelaajistolla oli aiempaa pääsarjakokemusta Viipurin ja Enson joukkueista. (Helsingin Sanomat 21.4.1941, 8; Karjala 20.3.1941.) Puna-Mustien nimi oli kytköksissä luovutetun Karjalan pesäpalloiluun, sillä se viittasi Suomen Karjalan punamustissa peliasuissa 1930-luvulla pelanneeseen Viipurin Pallonlyöjiin, lempinimeltään "Viipurin puna-mustat" (Jyrkiäinen 2017; Karjala 15.8.1932, 5). Jatkosodan jälkeen vuonna 1945 Puna-Mustien pääsarjapaikan sai Hukat, joka oli Viipurin Palloseuran pelaajien Helsingissä sodan aikana perustama urheiluseura. Vuonna 1948 pesäpalloilu jatkui Puna-Mustien nimellä. (Jyrkiäinen 2017.) Vielä 1940-luvun lopun kirjoituksissa Puna-Mustien naisten joukkueen nimen perässä saattoi nähdä sulkumerkeissä nimen 'Hukat' (Etelä-Suomen Sanomat 2.4.1949, 5). Vuonna 1968 Puna-Mustat ${ }^{19}$ siirtyi pelaamaan kotiotteluitaan Hesperian kentältä Meilahden vastavalmistuneelle pesäpallokentälle, mikä on yhä seuran aktiivisessa käytössä.

Pesäpalloseura Puna-Mustien punamustilla verkkosivuilla iskulauseena on "stadilaista pesistä" (Puna-Mustat). Toisaalta seura on alleviivannut karjalaista taustaansa punamustien peliasujensa lisäksi logolla, joka on muunnelma perinteisestä Ruotsin/Suomen Karjalan vaakunasta. Pienikokoinen logo koristaa myös seuran punamustia peliasuja ja juomapulloja. Perinteisistä Karjala-viittauksista kiinni pitäminen ei ole ollut evakkotaustaa omaaville urheiluseuroille itsestäänselvyys, sillä useiden siirtokarjalaistaustaisten urheiluseurojen symboliikassa viittaukset luovutettuun Karjalaan ovat väistyneet hiljalleen vuosikymmenten myötä. ${ }^{20}$ Toisaalta Suomen ajan Viipurissa toimineista ja muualla Helsingissä toimintaansa jatkaneista urheiluseuroista esimerkiksi Viipurin Urheilijat on edelleen iso ja aktiivinen seura, joka tukeutuu imagossaan Suomen Karjalan punamustiin väreihin (Viipurin Urheilijat). Lisäksi esimerkiksi jalkapalloseurat PK-35 ja PK-35 Vantaa ovat jatkaneet Viipurin Pallokerhon toimintaa pääkaupunkiseudulla pitäen kiinni punamustista peliasuista (Helsingin Sanomat 26.8.2020). Perinteiset Suomen Karjalan värit ja vaakunakuvio johdattelevat ajattelemaan Puna-Mustat-pesäpalloseuraa ja sen pelikenttää muiden edellä mainittujen urheiluseurojen tavoin viipurilaisuutta ja karjalaisuutta ohuesti indikoivana muistin paikkana. Puna-Mustien symbolisissa Karjala-viittauksissa on säilytetty yhteys seuran ja siirtokarjalaisuuden välillä, millä ei kuitenkaan ole haluttu poissulkea seuran helsinkiläisyyttä. Huomionarvoista on myös se, että Puna-Mustien tapauksessa Karjala-symboliikkaa on säilytetty kansallislajiksi perinteisesti mielletyn ja etenkin maakunnissa suositun pesäpallon yhteydessä.

Kun viipurilainen siirtoväki kuuli Meilahdessa kerrostalonsa ikkunasta kotoisaa murretta, he saattoivat kuulla myös Viipurista tuodun kirkonkellon soivan. Vuonna 1954 käyttöön vihityn, Markus Tavion suunnitteleman Meilahden luterilaisen kirkon tapuliin on nostettu kaksi kelloa, joista pienempi oli alun perin määrä asentaa Viipurin uuteen tuomiokirkkoon. Kirkko tuhoutui talvisodassa, eikä sitä ehditty rakentaa uudelleen jatkosodan aikana. Sodan aikana Tampereen Lokomossa valettu, Viipuriin viittaavalla tekstillä varustettu kello evakuoitiin sodan yhteydessä Suomeen. Ennen kellon lahjoittamista Meilahden kirkolle sen kerrotaan lojuneen rautatiepysäkillä ja olleen Viipurin tuomiokirkkoseurakunnan hoitokunnan omaisuutta. (Helminen 2020, 251-252; Helsingin seurakuntayhtymä 2017; Uusi Suomi 6.7.1953, 1.) Kenttämatka Meilahden

19 Puna-Mustat voitti 1970-luvulla Suomen mestaruuksia miesten ja naisten sarjoissa ja pelasi vuonna 2021 miehissä kolmanneksi ylimmällä sarjatasolla ja naisissa Eteläisen alueen maakuntasarjassa (Puna-Mustat).

20 Esimerkiksi Viipurin Reippaan, sittemmin Lahden Reippaan, jääkiekkojoukkueen Kiekkoreippaan pelihousuissa oli Viipurin linnan tornin kuva 1980-luvulle saakka (Helsingin Sanomat 23.12.2013). 
kirkolle kesäkuussa 2021 osoitti, että Suomen Viipurin historiaan kiinnittyvä artefakti on asetettu osaksi skandinaavishenkistä rakennuskokonaisuutta.

Meilahden kirkonkellon ääni kuuluu lähitienoille, minne on tuotu ja rakennettu lisää muistoja luovutetusta Karjalasta. Läheisessä Seurasaaressa sijaitsevaan ulkomuseoon kuljetettiin kesällä 1939 Pertinoksan karjalaistalo Raja-Karjalan Suojärveltä (Museovirasto). Töölön puolella Nordenskiöldinkadulle kohosi vuosina 1953-1956 Alvar Aallon suunnittelema Kansaneläkelaitoksen pääkonttori, jonka lukusali on pienoiskopio Aallon suunnittelemasta Viipurin kirjaston salista. Salien arkkitehtonisia piirteitä on nähtävissä Aallon suunnittelemissa kirjastoissa laajemminkin, joten Töölöön rakennettu salikopio ei ole tässä suhteessa yksiselitteisen viipurilainen artefakti. Viipurilaistaustaisista yrityksistä Töölössä toimivat edelleen esimerkiksi Viipurin hautaustoimisto, Wiipurin Korsetti ja Ravintola Lehtovaara. Lisäksi Helsingissä toimii ainakin 36 viipurilaistaustaista yhdistystä, joista suuri osa pitää aktiivisesti yllä Viipuri-muistoja.

Nyky-Meilahden fyysisessä kaupunkitilassa karjalaisuutta tai viipurilaisuutta on vahvasta muisteluperinteestä huolimatta melko vaikea havaita: siellä ei voi enää nähdä selkeästi hahmottuvaa Pikku Viipuria. Meilahden karjalaisuus ja viipurilaisuus näyttäytyvät ennen kaikkea elettynä ja koettuna siirtoväen historiana, mikä on vastakuvaa järjestövetoiselle, etenkin Karjalan Liiton, identiteettityölle ja varainkeruin pystytetyille julkisille monumenteille. Lähihistoriansa osalta Meilahtea voi pitää yhtenä niistä toisen maailmansodan jälkeisistä Pikku Viipureista, joita muodostui ja rakennettiin viipurilaisen siirtoväen asuinkeskittymiin eri puolille Suomea. Meilahden Pikku Viipuria on vaikea rinnastaa globaalien muuttoliikkeiden myötä syntyneisiin ja vuosikymmenten ajan tunnistettavuutensa säilyttäneisiin etnisten vähemmistöjen urbaaneihin asuinkeskittymiin, kuten italialaissiirtolaisten eri puolille maailmaa rakentamiin Pikku Italia -kaupunginosiin (engl. Little Italy). Kulttuurierojen korostumisen ja pienelle alueelle keskittymisen sijasta viipurilaisuus ja siirtokarjalaisuus ovat nykyisin sulautuneet osaksi helsinkiläisyyttä ja yleissuomalaisuutta pilkahtaen esiin muistin paikoissa eri puolilla himmenevää Meilahden Pikku Viipuria ja koko pääkaupunkia.

\section{Muistojen talo Käpylässä}

Helsingissä oli rakennettu ja suunniteltu Karjalaan viittaavia yhteisöjen kokoontumistiloja jo ennen toisen maailmansodan evakkojen saapumista. Karjalainen Osakunta oli rakennuttanut 1900-luvun alussa Kruununhaan Liisankatu 17:ään jykevällä kansallisromanttisella graniittijulkisivulla varustetun Karjalaisten talon, mutta talousvaikeuksien vuoksi osakuntien toiminta kiinteistössä oli loppunut jo ensimmäisen maailmansodan aikaan (Karjalainen Osakunta). Keskustelut edellä mainitusta Kalevalaseuran massiivisesta Kalevalatalo-hankkeesta olivat käynnistyneet 1920-luvun alussa. Muutoinkin suomalaisessa kulttuurielämässä näkyi 1920- ja 1930-luvuilla tunteita nostattava Kalevala-innostus ja siihen liittyvä Itä-Karjala-entusiasmi, jossa sekä Viena että Aunus näyttäytyivät Suur-Suomi-haaveiden kautta Karjalan ydinalueina.

Toisen maailmansodan jälkeinen siirtokarjalaisyhdistysten perustamisaalto loi uudenlaista kysyntää karjalaisyhteisöjen toimitiloille Helsingissä: esimerkiksi Pääkaupungin Karjalaisten kokouksessa yhteistä toimintataloa karjalaisyhdistyksille ideoitiin 1940- ja 1950-lukujen taitteessa (Pääkaupungin karjalaisten vuosikokousten pöytäkirjat 1949 ja 1950). Kalevalatalo-suunnitelmat herättivät 1960-luvun alussa kiinnostusta Karjalan Liitossa, joka tuki 


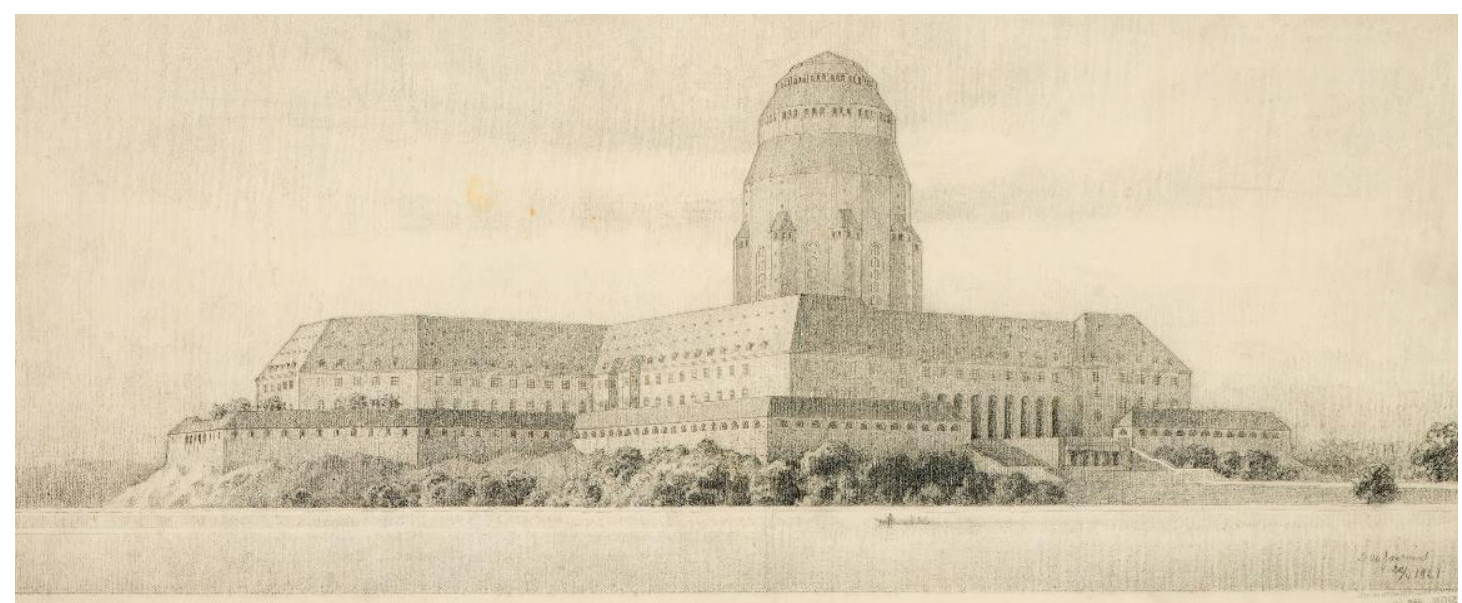

Kuva 3. Helsingin Munkkiniemeen suunniteltu Kalevalatalo. Piirros Eliel Saarinen 1921. Kansalliskirjasto.

hetkellisesti aloitetta Kalevalatalon rakentamisesta Suomen itsenäisyyden 50-vuotisjuhliin mennessä (Suoninen 2004, 15, 18). Loppuvuonna 1966 Karjalan Liitto anoi Helsingin kaupungilta vuokratonttia toimitalon rakentamista varten muttei ryhtynyt rakentamaan kiinteistöä kaupungin tarjoamalle tontille Pohjois-Haagaan (Helsingin Sanomat 28.12.1966, 9; Suoninen 2004, 19). Näihin aikoihin Karjalan Liitto tiedusteli mahdollisuuksia päästä mukaan Kalevalaisten Naisten Liiton talohankkeeseen, joka koski Kallion kirkon lähistölle rakennettavaa kiinteistöä (Suoninen 2004, 19).

Pääkaupungin karjalaisyhdistykset, -säätiöt, -osakunnat ja Karjalan Liitto pyysivät vuonna 1969 Helsingin kaupungilta tonttia toimitalon rakentamista varten, mihin tarkoitukseen kaupunginhallitus teki heille vuoden 1971 loppuun ulottuneen tonttivarauksen osoitteesta Käpylänkuja 1 (Helsingin kaupunginhallituksen kokouspöytäkirja 30.6.1969). 1970luvun alussa Lappeenrannan kaupunki tarjosi tonttia ja tukea heimotalon rakentamiseksi Helsingin sijasta Lappeenrantaan (Suoninen 2004, 21). Eri puolilla Suomea toimineet siir-

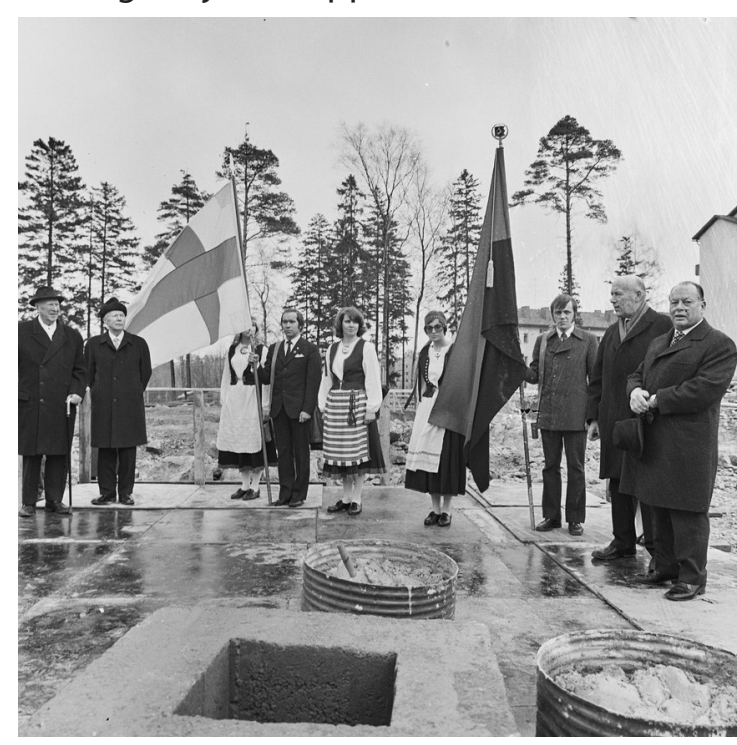

Kuva 4. Helsingin Käpylään nouseva Karjalatalo. Karjalatalon peruskiven muuraus 1973. Valokuvaaja Pekka Kyytinen. Museovirasto. tokarjalaisyhteisöt eivät olleet yksimielisen suopeita Helsingin rakennushankkeelle (Suoninen 2004, 29; ks. myös Etelä-Suomen Sanomat 11.12.1974, 13). Anottuaan Käpylässä sijaitsevalle tontille lisäaikaa karjalaistoimijat perustivat syksyllä 1972 Kiinteistö Oy Karjalaisten Heimotalon (Suoninen 2011, 166). Tässä vaiheessa osakunnat olivat jättäytyneet pois talohankkeesta. Varainkeruu Karjalataloa varten oli mittava: hanke esitettiin karjalaisen heimon ja koko Suomen asiana (Helsingin Sanomat 8.3.1970, 42), ja rahankeruuilmoituksia julkaistiin Pohjois-Amerikassa saakka (Canadan viesti 1.2.1972, 3). Varainkeruuhankkeen sloganina oli "Karjalatalo - kulttuurivelka Karjalalle" (Karjalatalo-hankkeen esittelyvihkonen n. 1972, Impilahti-Seuran arkisto). 
Pitkään suunnitteilla olleen kiinteistön peruskivenmuurausseremoniaa vietettiin Helsingin Käpylään raivatulla tontilla helmikuussa 1973. Harvakseen pystyyn jätetyt männyt reunustivat aluillaan olevaa rakennustyömaata, jonka keskellä Suomen sinivalkea ja Suomen Karjalan punamusta lippu liehuivat kantotangoissa pitelijöinään kaksi nuorehkoa miestä. Lippujen molemmin puolin seisoi siisteihin, tummiin asuihin pukeutuneita kaupungin johtohenkilöitä ja Karjalan Liiton edustajia. (MV/KK/5596/6/JÄR/13.) Tarinan mukaan betoniin kätkettiin talon perustamisasiakirja, Karjalan Liiton säännöt ja vuosikertomus, Kiinteistö Oy Karjalaisten Heimotalon yhtiöjärjestys, viimeisin Karjala-lehden ${ }^{21}$ numero sekä huolellisesti Suomen historian ajalta koottu valikoima kolikoita (Korppi 2007, 142). Helmikuussa 1974 paikallinen Käpylä-lehti kertoi rakennusvaiheen olleen niin pitkällä, että talon julkisivua pestiin ja punainen tiili tuli kauniisti näkyviin (Käpylä-lehti 2/1974, 3). Marraskuussa 1974 Käpylänkuja 1:ssä vihittiin käyttöön kolmikerroksinen tiilirakennus, Karjalatalo.

Talon vihkiäispuheessaan Karjalan Liiton puheenjohtaja Urho Kähönen rakensi yhteyden Karjalassa eläneiden sukupolvien ja toisen maailmansodan jälkeisen järjestötoiminnan välille, jonka kautta hän hahmotteli elinvoimaista ja yksimielistä karjalaista heimoa. ${ }^{22}$ Tämän kuvitellun yhteisön ympärille luotiin puheessa menetykseen ja menneisyyteen pohjautuva uhrinarratiivi, jota Karjalan Liitto oli korostanut jo edellisvuosien aikana kerätessään rahoitusta talohankkeelleen. Tässä isänmaallishenkisessä kertomuksessa karjalaisen heimon olemassaoloa pyrittiin vahvistamaan ja oikeuttamaan se esittämällä Karjalan siirtoväki valtiollisen vapauden mahdollistajana, uhriheimona, jonka katsottiin luovuttaneen kotiseutunsa koko Suomen puolesta. Myös sittemmin Karjalatalon rakentamista ja kiinteistössä tapahtuvaa karjalaisyhteisöjen toimintaa on käsitelty teksteissä, jotka pyrkivät vahvistamaan ajatusta karjalaisten kollektiivisesta toimijuudesta (mm. Suoninen 2011) ja joissa on tunnistettavissa karjalaisuutta romantisoiva pohjavire (esim. Etelä-Suomen Sanomat 15.7.1977, 8).

Karjalatalo on vuosikymmentensä aikana muodostunut etupäässä siirtokarjalaisyhdistysten toimintakeskukseksi ja olohuoneeksi. Karjalan Liiton organisoima toiminta on ollut pääosassa kiinteistön käyttöhistoriassa, mutta talossa ovat toimineet myös muut yhteisötoimijat, kuten Suomen Inkeri-liitto ja Inkeriläisten sivistyssäätiö, joilla on yhä toimintaa kiinteistössä. Karjalatalon tiloja on voinut vuokrata avoimesti, ja siellä on järjestetty monenlaisia tapahtumia, kuten karjalaisyhteisöjen juhlia, iltapäivätansseja ja teatteriesityksiä (Helsingin Uutiset 25.2.2020). Kiinteistössä ovat pitkään toimineet karjalaista perinneruokaa tarjoileva Ravintola Karelia (Karjala 28.11.1974; Ravintola Karelia) ja Karjalan Liiton puoti. Lisäksi talossa toimii kuntosali ja Käpylän musiikkiopiston kansanmusiikkilinja.

Karjalatalon ympärillä on käyty myös patsaskeskusteluja. Karjalan Liitto yritti siirtää 1980-luvulla Larin Parasken muistomerkin päämajansa edustalle Käpylään siinä onnistumatta

21 Karjala-lehti ja Karjalan Liitto ovat tehneet tiedotusyhteistyötä vuodesta 1958 alkaen (Karjalan Liiton kiertokirje 5/58, Pääkaupungin karjalaiset ry:n arkisto).

22 Kähönen päätti puheensa seuraavasti: "Nyt vihittävän Karjalatalon on Karjalan heimo voimansa kooten ja ystäviensä apuun tukeutuen rakentanut eläväksi ja toimivaksi muistomerkiksi menneiden sukupolvien työlle, heidän jättämänsä kulttuuriperinnön vaalimiseksi ja järjestötoiminnan tyyssijaksi. Kertokoon tämä heimotalo hajalleen sirotellun karjalaisen heimon elinvoimasta ja yksimielisyydestä sekä siitä suuresta uhrista, jonka heimo on antanut joutuessaan luovuttamaan kotiseutunsa isänmaan vapauden lunnaiksi. Vallitkoon tämän talon seinien sisällä se elävä karjalainen henki, jonka Karjalasta tänne siirtyneet henkisenä perintöosanaan toivat tullessaan ja jonka he toivovat jäävän perinnöksi heidän nouseville sukupolville." (Karjala 21.11.1974, 1.) 
(Helsingin Sanomat 19.6.1987, 7). Sittemmin, vuonna 2014, Karjalatalon rakennuspiirustuksiin lisättiin suunnitelma julkisesta veistoksesta (Karjalatalon rakennuspiirustukset, 25/2721/14/C, Lupapiste), ja vuonna 2015 sen edustalle pystytettiin Juhani Honkasen suunnittelema, huivipäistä naista ja kahta lasta esittävä Evakkoäiti-patsas. Sotien runtelemaa evakkoperhettä symboloivan monumentin jalustaan kaiverrettiin karjalaissukuisen elokuvaohjaaja Lauri Törhösen mietelause "vaikka kotimme taakse jäi, jäi eteemme elämä". Elokuvaohjaajaan tammikuussa 2018 kohdistuneiden ahdistelusyytösten jälkeen Karjalan Liitto peitti tekstin laatalla, jossa yhdistyivät kalevalaiset sanankäänteet ja inhimillinen toteutus tai kiire: laatassa oli säkeitä Kantelettaresta, se poikkesi patsaan alkuperäisestä värimaailmasta, eikä sitä ollut mitoitettu peittämään alkuperäistä kaiverrusta kokonaisuudessaan. Laatan tekstinä oli "Muinaiset ajat paremmat, pois otti minun poloisen, kauas kantoi Karjalasta, näille ouoille oville, veräjille vierahille". Karjalan Liiton puheenjohtaja Pertti Hakanen kertoi, että syynä hänen ehdotukselleen tekstin vaihtamiseksi oli "huono luettavuus". Pian laatta kuitenkin poistettiin, sillä patsaan tekijänoikeudet omaava ja asiassa kokonaan kuulematta jäänyt taiteilija Juhani Honkanen ei pitänyt laatasta. (Helsingin Sanomat 17.3.2018, A 26; Helsingin Sanomat 20.3.2018.)

Suomalaiskansallista evakkokarjalaisuuskuvastoa toisen maailmansodan jälkeen keskeisesti rakentaneen Karjalan Liiton viime vuosikymmenten patsaspyrinnöissä on nähtävissä myös edistyksellinen tasa-arvon elementti. Useimmat evakkomuistomerkit Suomessa kuvaavat sotaa tai miehiä, mutta rakentaessaan kadonneen Karjalan muistojen olohuonetta "Käpylän kankahille" Karjalan Liitto on ollut avoin naisia esittäville patsaille. Karjalaisuuden identifikaatiot näyttävätkin mukailevan jo fennomaanien karjalaisiin liittämiä heimostereotypioita, kuten herkkyyttä, verbaalisuutta ja taiteellisuutta sekä sodanjälkeisen ajan surua ja kärsimystä. Larin Parasken ja Evakkoäiti-patsaiden ympärillä käydyt keskustelut osoittavat, että muistomerkein ylistetyt kohteet voivat tulla vaihdetuiksi, siirretyiksi tai nousta postuumisti jalustoille.

Kolmikerroksinen, tiiliseinäinen Karjalatalo poikkeaa Käpylän muusta rakennusprofilista, jota hallitsevat vuodelle 1940 suunniteltuja ja vuonna 1952 pidettyjä olympialaisia varten rakennetut kerrostalot sekä varhaisemmat puutalot. Oman aikansa arkkitehtuuria edustavan Karjalatalon ja ympäristön yhteisvaikutelma ei ole kaikkein harmonisin: turistin silmissä Karjalatalo voisi helposti näyttää yksinäiseltä oppilaitokselta tai virastolta keskellä uneliasta asuintaloidylliä. Nämä vaikutelmat johdattavat ajattelemaan Karjalataloa eräänlaisena Kalevalatalo-hankkeen henkisenä perillisenä. Myös silmäys Karjalatalon sisälle tukee ajatusta. Karjalan Liitto on toteuttanut Karjalatalossa pienoiskoossa jokseenkin Kalevalatalon suunnitelmia muistuttavaa kollektiivisen identiteetin ohjelmaa aiheenaan suomalais-kalevalaisuuden sijasta luovutettu Karjala. Karjalatalon salit on nimetty entiseen Viipurin lääniin viittaavilla maantieteellisillä nimillä - Laatokka, Sortavala, Wiipuri ja Käkisalmi/Wärtsilä. Talossa on ekumeeninen kappeli, Karjalan Liiton käsikirjasto, edellä mainitut puoti ja ravintola, ja juhlasalissa punakankaiset istuimet ja seinille asetetut luovutettujen paikkakuntien vaakunarivistöt täydentävät Karjala-viittausten symbolistoa. Toisaalta Karjalatalosta puuttuu hahmo- ja henkilöpalvonnallinen aspekti, mikä näyttäytyi Kalevalatalon suunnitelmissa keskeisenä.

\section{Johtopäätökset}

Tarkastelemamme kolme Helsingissä sijaitsevaa muistin paikkaa avaavat näkymiä moni-ilmeisiin karjalaisuuskäsityksiin: Larin Parasken muistomerkki viittaa suomalais-kalevalaiseksi 
koettuun karjalaisuuteen, Meilahden katunäkymä puolestaan suomalaisen Viipurin historiaan ja Käpylän kaupunginosassa sijaitseva Karjalatalo järjestövetoiseen siirtokarjalaisuuteen. Kohteiden historiat osoittavat, kuinka sykleittäin yksittäisten ihmisten ja yhteisötoimijoiden aktiivisuuteen perustuvaa Karjala-symboliikkaa on sulautunut osaksi Helsingin kaupunkitilaa ja kuinka vahvasti sen taustalla ovat vaikuttaneet poliittiset suhdanteet. Arvioimissamme muistin paikoissa karjalaisuus ilmenee yhtäältä kadonneen ja kuvitellun suomalaisen Karjalan siirtämisenä uuteen kaupunkitilaan, ja toisaalta osoituksena siitä joustavuudesta ja mukautumisesta, mitä Karjalasta muuttaneilta ihmisiltä ja yhteisöiltä on vaadittu uudessa lokaatiossa.

Larin Parasken muistomerkki on rakentanut karjalaisuutta Helsingissä erityisen moniselitteisesti. Ensiksikin patsas on keskeisen sijaintinsa kautta tuonut pääkaupungin ydinkeskustaan viittauksen Karjalankannaksen rajaseudun historiaan ja karjalaiseksi miellettyyn runonlauluun. Se on tapausesimerkki paikka- ja aikasidonnaisten rajojen yli ulottuvasta runonlaulukarjalaisuudesta, jota halutaan yhä esitellä pilkahdusmaisesti osana Helsingin urbaania identiteettiä. Kuten Helsingin ydinkeskustan patsasgallerian kulttuurisissa valtasuhteissa, ovat Karjalaan ja karjalaisuuteen kiinnittyvät symbolit olleet sivuuttamattomia myös suomalaisen kansakunnan kertomuksessa. Toisaalta Larin Parasken patsaan ovat kokeneet omakseen myös muut kuin karjalaistoimijat. Parasken muistomerkin synty- ja julkistamiskonteksteihin liittyy Kalevalaseuran edustamaa suomalaiskansallista karelianismia, kalevalaisten naisyhdistysten isänmaallista henkeä sekä Keskusosuusliike Hankkijan edustamaa agraari-Suomen arvomaailmaa. Sen sijaan siirtokarjalaisyhdistykset kiinnostuivat muistomerkistä toden teolla vasta sen pystyttämisen jälkeisinä vuosikymmeninä. Nykyisin patsaan moniselitteisyyttä lisää se, etteivät Paraske henkilönä ja hänen muistomerkkinsä ole myöhempien polvien keskuudessa yksiselitteisen hyvin tunnettuja.

Meilahden himmenevä Pikku Viipuri on esimerkki viipurilaisuuden ja siirtokarjalaisuuden sulautumisesta osaksi yleissuomalaisuutta ja urbaania helsinkiläisyyttä. Alueelle sijoittuvan Viipurin tuomiokirkon kellon ja siellä toimivan Puna-Mustat-pesäpalloseuran kerrokselliset menneisyydet osoittavat Larin Parasken patsaan tavoin, että näkyväksi tehty historia muodostuu katkonaisista tapahtumakuluista ja että muistin paikkojen - sekä niistä esitettyjen myöhempien tulkintojen - taustalta näyttää löytyvän yhteisöjen moninaiset toimintamotiivit. Meilahden Pikku Viipurin historiassa korostuu siirtokarjalaisuus arjen ja muistelun tasolla, eivätkä esimerkiksi kulttuuriperintöä vaalivat yhdistykset ole (ainakaan vielä) pystyttäneet alueelle evakkomuistomerkkiä. Tällainen narratiivisuuteen pohjautuva siirtokarjalaisuus tuo lisäkerrostuman alueen ja koko Helsingin karjalaisuuteen, vaikka sen merkit fyysisessä kaupunkitilassa voivatkin olla vähäisiä. Narratiivisen karjalaisuuden välittyminen yhä uusille sukupolville on keskeinen ehto, jotta Helsingin urbaania identiteettiä rikastuttavat kaupunkikarjalaiset muistin paikat, kuten Meilahden stadionille kokoontuva Puna-Mustat-pesäpalloseura Karjala-symboleineen, voivat tulla ymmärretyksi edes osittain karjalaisina.

Karjalatalon rakentaminen Helsinkiin siirtokarjalaisyhdistysten valtakunnalliseksi keskukseksi antaa aihetta ajatella pääkaupunki Helsinkiä luovutetun Karjalan symbolisena aluekeskuksena. Suomalainen Viipurin lääni on Helsingissä yhä osa Suomea: se kuvitellaan ja sitä vahvistetaan muistin paikoin, joista keskeisin on Karjalatalo, kadonneen suomalaisen Karjalan planetaario. Samalla Karjalatalo on kolossaalinen ilmentymä siirtokarjalaisyhdistysten vireästä ja identiteettihakuisesta järjestötoiminnasta sodan jälkeisinä vuosikymmeninä. Nykyisin, kun Karjalatalo lähestyy peruskorjausikää ja Karjalan Liiton jäsenistö ikääntyy ja 
vähenee, rakennuksen tulevaisuuden ympärillä leijuu menneiden vuosikymmenten järjestökarjalaisuuden kokoinen kysymysmerkki.

Siirtokarjalaisuuden ja sitä vanhemman karjalais-kalevalaisuuden kohtaamisista muodostuva helsinkiläinen kaupunkikarjalaisuus ilmenee tarkastelemiemme kohteiden perusteella pääpiirteittäin kolmella tavalla. Ensiksikin se hahmottuu karelianistiseen Karjala-innostukseen ja Kalevala-romantiikkaan kytkeytyvinä ajallisina kerrostumina, joista Larin Parasken patsas on tapausesimerkki. Tämä karjalais-kalevalainen pohja oli jo olemassa kaupungissa, kun seuraavaa merkittävää karjalaisuuden kerrostumaa, siirtokarjalaisuutta, ryhdyttiin rakentamaan kaupunkitilaan evakoiden saapumisen myötä. Siirtoväkeä virtasi Helsinkiin huomattavasti enemmän kuin asutussuunnitelmissa kaavailtiin, ja pääkaupunkiin siirrettiin, perustettiin ja rakennettiin monia luovutettuun Karjalaan viittaavia muistin paikkoja, kuten Viipurin kirkonkello, Puna-Mustat-pesäpalloseura ja kaikkein tärkeimpänä Karjalatalo. Kolmas kaupunkikarjalaisuuden taso on edellä mainittujen kerrostumien kohtaaminen 2020luvun kaupunkitilassa. Runonlaulajapatsas ja Meilahden himmenevä Pikku Viipuri ovat jäämässä muistin paikoiksi, jotka ovat merkityksellisiä lähinnä asiaan vihkiytyneille harrastajille ja kulttuuriperintöä vaaliville tahoille. Kaupunkikarjalaisuus ilmenee nyky-Helsingin julkisessa tilassa sirpaleisena, eikä moninaisista karjalaisista muistin paikoista muodostu yhtenäistä ja selväpiirteistä kokonaisuutta. Kollektiivisia karjalaisuuskuvia manifestoivat nykyisin lähinnä lukuisat yhdistykset, joiden pääasiallinen kokoontumispaikka Karjalatalo on Helsingin karjalaisuuden keskipiste.

Lopulta Helsingin urbaanin identiteetin, kuten myös sitä konstruoivien tutkimusten, tekeminen on kulttuuristen merkitysvalikoimien kokoamista yhdistelemällä ajallis-tilallisia lähtö- ja paluupisteitä. Se on merkintöjen tekemistä mentaaliselle kartastolle, jolle heijastetut inmiset, kuvitellut yhteisöt, kaupungit, alueet, valtiot ja niiden väliset eriaikaiset suhteet asettuvat kulloistenkin limittäisten tarinoiden muotoihin. Yhtenäisinä esitetyt kulttuuriset muodostelmat kätkevät alleen poliittisten kontekstien ja merkkivuosien ympärille sykleittäin punoutuvia tapahtumaketjuja ja menneisyyden maiseman, jolle on ominaista - Helsingissä tarkastelemiemme karjalaisten muistin paikkojen tavoin - kerroksellisuus ja moniulotteisuus.

\section{Lähteet}

\section{Tutkimusaineistot}

Tutkimushankkeessa "Urbaani karjalaisuus" kerätty aineisto 2019-2021. Karjalan tutkimuslaitos, Itä-Suomen yliopisto.

Helsingin kaupunkitilan kaupunkisuunnistus 7.6.2021, klo 9.00-18.00 (kirjoittajat).

\section{Arkistoaineistot}

Helsingin kaupunginarkisto, Helsinki (Hka):

Kaupunginhallituksen pöytäkirjat 1949 Ca:19, 1969 Ca:39

Kaupunginhallituksen pöytäkirjain liitteet 1949 Cb:130-131

Helsingin kaupunginmuseo:

Kuvakokoelma 
Helsingin seudun aluesarjat:

Helsingin tulo- ja lähtömuutto lääneittäin 1911-1994. http://www.aluesarjat.fi

Kansallisarkisto:

Pääkaupungin karjalaiset ry:n arkisto

Ca. Vuosikokousten pöytäkirjat 1946-71

Saapuneet asiakirjat

Impilahti-Seuran arkisto

Hallinto- ja talousasiat 1948-2010

Kansalliskirjasto:

Finnan kuvakokoelma

Lupapiste:

Karjalatalon piirustukset, Käpylänkuja 1

25/2721/14/C

Museovirasto:

Kansatieteen kuvakokoelma

Pekka Kyytisen kokoelma

Suomalaisen Kirjallisuuden Seura

KRA. Helsinki - Stadini -kirjoituskilpailu 2004-2005.

\section{Lehdistö}

\section{Canadan viesti 1972}

ET 1999

Etelä-Suomen Sanomat 1949, 1974, 1977, 1984, 2005

Helsingin Sanomat 1928, 1933, 1941, 1949, 1958, 1962, 1966, 1970, 1981, 1987, 1995, 1997, 2013, 2018, 2020

Helsingin Uutiset 2020

Ilta-Sanomat 1936

Inkeriläisten viesti 1961, 1998

Karjala 1932, 1941, 1974, 2004

Karjalan Heimo 1970

Käpylä-lehti 1974

Länsi-Savo 1995

Nuori Karjala 2004

Pirta 1996

Päivälehti 1902

Rautulaisten lehti 1983

Suomen Kuvalehti 1935, 1979, 1992

Suomen Sosialidemokraatti 1954

Uusi Aura 1939

Uusi Suometar 1914

Uusi Suomi 1949, 1953, 1966

Uusimaa 1979

Vaasa 1934

Valvoja 1920

Viipurin Sanomat 1911

Wiipurin Sanomat 1885. 


\section{Kartat}

Helsingin kaupungin karttapalvelu. https://kartta.hel.fi.

\section{Kuvat}

49/362/D. Kalevalatalo, Munkkiniemi, Helsinki, ulkoperspektiivipiirustus, 20.4.1921. Tekijä: Eliel Saarinen. Finnan kuvakokoelma. Kansalliskirjasto.

HKL/93/568. Päiväkotilapsia ylittämässä suojatietä Kuusitien raitiovaunupysäkillä Mannerheimintiellä syyskuussa 1975. Kuvaaja: Unto Laitila. Helsingin kaupunginmuseon valokuvakokoelma. Helsingin kaupunginmuseo.

MV/KK/5596/6/JÄR/56. Rautu-Seuran lähetystö kunniakäynnillä Larin Parasken muistopatsaalla Hakasalmen puistossa Helsingissä tammikuussa 1974. Kuvaaja: Pekka Kyytinen. Kansatieteen kuvakokoelma, Pekka Kyytisen kokoelma. Museovirasto.

MV/KK/5596/6/JÄR/76/13. Karjalatalon peruskiven muuraus Käpylässä helmikuussa 1973. Kuvaaja: Pekka Kyytinen. Kansatieteen kuvakokoelma, Pekka Kyytisen kokoelma. Museovirasto.

\section{Audiovisuaaliset tallenteet}

Finlandia-katsaus 119. 1949. Finlandia Kuva Oy.

\section{Kirjallisuus}

Agulhon, Maurice. 1978. "La Statuomanie et l'Histoire." Ethnologie Française 8(2-3): 145-172. Ankersmit, Frank. 1999. "Remembering the Holocaust. Mourning and Melancholia." Teoksessa Historical Perspectives on Memory, toimittanut Anne Ollila, 94-95. Helsinki: Suomen Historiallinen Seura.

Assmann, Jan. 1995. "Collective Memory and Cultural Identity." New German Critique 65, Cultural History / Cultural Studies (Spring-Summer): 125-133. https://doi. org/10.2307/488538

Berggren, Lars. 1999. "The "Monumentomania" of the nineteenth century: causes, effects and problems of study." Teoksessa Memory \& oblivion, Proceedings of the XXIXth International Congress of the History of Art held in Amsterdam, 1-7 September 1996, toimittaneet Wessel Reinik \& Jeroen Stumpeö, 562-564. Dordrecht: Kluwer Academic Publishers.

Brummett, Barry. 2019. Techniques of Close Reading. SAGE Publications, Inc. https://dx-doiorg.ezproxy.uef.fi:2443/10.4135/9781071802595.

Davydova-Minguet, Olga. 2015. "Voitonpäivänjuhla Sortavalassa. Juhlinnan ja muistin politiikkaa rajakaupungissa." Elore 22(2): 1-32. https://doi.org/10.30666/elore.79218.

Fingerroos, Outi. 2006. "Karjala - muistin ja utopian paikka." Alue ja ympäristö 35(2): 3-14. https://aluejaymparisto.journal.fi/article/view/64290.

Fingerroos, Outi ja Jaana Loipponen (toim.). 2007. Nykytulkintojen Karjala. Nykykulttuurin tutkimuskeskuksen julkaisuja 91. Jyväskylä: Jyväskylän yliopisto.

Green, Anna. 2008. Cultural History. Houndmills: Palgrave Macmillan.

Grönholm, Pertti ja Anna Sivula (toim.). 2010. Medeiasta pronssisoturiin. Kuka tekee menneestä historiaa? Turku: Turun historiallinen yhdistys. 
Halbwachs, Maurice. (1925/1941) 1992. On Collective Memory. (Les cadres sociaux de la mémoire: La topographie légendaire des Evangiles en Terre sainte: Étude de mémoire collective). Toimittanut ja kääntänyt Lewis A. Coser. Chicago: The University of Chicago Press.

Hargrove, June. 2005. "Qui vive? France! War Monuments from the Defense to the Revanche." Teoksessa Studies in the History of Art 68, Symposium Papers XLV: Nationalism and French Visual Culture, 1870-1914, 54-81. https://www.jstor.org/stable/42622392.

Helminen, Martti. 2020. "Viipuria Helsingissä 2000-luvulla." Teoksessa Viipuri. Historiallinen kaupunkikartasto, toimittaneet Kimmo Katajala, Marjatta Hietala, Pirjo Uino, Martti Helminen, Antti Härkönen ja Helena Hirvonen. Helsinki: AtlasArt.

Helsingin kalevalaiset naiset. "Louhi, Pohjolan emäntä." https://www.hkn.fi/fi/ helsingin-kalevalaiset-patsaat/louhi-pohjolan-emanta/.

Helsingin kaupunkisuunnitteluvirasto. 1977. "Meilahden huvila-alue." https://www.hel.fi/ hel2/ksv/julkaisut/YB20 76 1.pdf.

Helsingin kaupunkisuunnitteluvirasto. 2014. "Meilahden huvila-alue. Ympäristöhistoriallinen selvitys." https://www.hel.fi/static/hkr/hoito ja kehittamissuunnitelmat/meilahden huvila_ymphistoriallinen_selvitys.pdf.

Helsingin Sanomat. 2013. "Lahti on Suomen viipurilaisin kaupunki." 23.12.2013. https://www. hs.fi/kotimaa/art-2000002698160.html.

Helsingin Sanomat. 2018. "Käpylän patsaskiista saa taas uusia kierroksia: Lauri Törhösen värssy kaivettiin takaisin esiin, ohjaajan teksti oli peitetty häthätää messinkilaatalla." Muokattu 20.3.2018. https://www.hs.fi/kaupunki/art-2000005611019.html.

Helsingin Sanomat. 2020. "Viipurilaisseuran perilliset kohtaavat." Muokattu 26.8.2020. https:// www.hs.fi/urheilu/art-2000006613614.html.

Helsingin seurakuntayhtymä. 2017. "Meilahden kirkko." https://www.helsinginseurakunnat. fi/sisaltokeskus/vmrgh8t3v.html.stx.

Helsingin Uutiset. 2020. "Viipurin historia elää yhä Helsingissä - hirvipatsas ja kuuluisa kirjastokin saivat kopion Töölöön." 30.4.2020. https://www.helsinginuutiset.fi/ paikalliset/1639800.

Helsingin Uutiset. 2020. "Käpylän suositut iltapäivätanssit jouduttiin keskeyttämään toistaiseksi - "Vaatii paljon vapaaehtoisia vetämään tällaista." 25.2.2020. https://www. helsinginuutiset.fi/paikalliset/1197403.

Hobsbawm, Eric. (1983) 2012. "Mass-Producing Traditions: Europe, 1870-1914." Teoksessa The Invention of Tradition, toimittaneet Eric Hobsbawm ja Terence Ranger, 263-307. Canto Classics. Cambridgeshire: Cambridge University Press. https://search-ebscohostcom.ezproxy.uef.fi:2443/login.aspx?direct=true \&db=nlebk\&AN=909820\&site=eh ost-live.

Hodgkin, Katharine ja Susannah Radstone (toim.). 2003. Contested Pasts. The Politics of Memory. Lontoo ja New York: Routledge.

Hämynen, Tapio. 2013. "Rajakarjalaisen kieliyhteisön rapautuminen ja karjalankielisten määrä Suomessa." Teoksessa Karjala-kuvaa rakentamassa, toimittanut Pekka Suutari, 182-213. Helsinki: Suomalaisen Kirjallisuuden Seura.

Ilmolahti, Oona ja Maria Lähteenmäki. 2021. "Moniaistinen Laatokka muistikokemuksena." Teoksessa Laatokka. Suurjärven kiehtova rantahistoria, toimittanut Maria Lähteenmäki, 205-233. Helsinki: Suomalaisen Kirjallisuuden Seura.

IImolahti, Oona, Maria Lähteenmäki, Sinikka Selin ja Anssi Neuvonen. 2021. "Biteillä maalatut omakuvat urbanisoituneessa Karjalassa." Historiallinen Aikakauskirja 119(1): 51-65. Helsinki: Suomen Historiallinen Seura. 
Jyrkiäinen, Pekka. 2017. "Kansallispeli Karjalassa - pesäpalloa luovutetussa Karjalassa vuosina 1922 - 1939" -näyttelymateriaali. http://www.mrasilainen.com/Karjala/karjala. htm.

Kanervo, Pirkko, Terhi Kivistö ja Olli Kleemola (toim.). 2018. Karjalani, Karjalani, maani ja maailmani. Kirjoituksia Karjalan menetyksestä ja muistamisesta, evakoiden asuttamisesta ja selviytymisestä. Turku: Siirtolaisuusinstituutti \& Oy Sigillum Ab.

Karjalainen Osakunta. "Historia." http://karjalainenosakunta.fi/osakunta/historia/.

Kivelä, Marjut. 1985. Sydämessä kalevalainen kansa. Alpo ja Nina Sailo runonlaulajien ikuistajina. Helsinki: Suomalaisen Kirjallisuuden Seura.

Knuuttila, Seppo ja Pekka Suutari. 2013. "Johdanto: Mikä pitää koossa Karjalaa?" Teoksessa Karjala-kuvaa rakentamassa, toimittanut Pekka Suutari, 9-25. Helsinki: Suomalaisen Kirjallisuuden Seura.

Korppi, Asta. 2007. Meidän Käpylä. Helsinki: Gummerus.

Lehikoinen, Jyrki (toim.). 1999. Helsingin kadunnimet. Helsingfors gatunamn. 3. Helsingin nimistötoimikunta. Helsinki: Gummerus.

Lento, Katri ja Pia Olsson. 2013. "Kaupunki, muistot ja muistaminen." Teoksessa Muistin kaupunki. Tulkintoja kaupungista muistin ja muistamisen paikkana, toimittaneet Katri Lento ja Pia Olsson, 7-27. Helsinki: Suomalaisen Kirjallisuuden Seura.

Lähteenmäki, Maria. 2012. "Karjalainen kaupunki?" Teoksessa Syrjäseudun idea. Kulttuurianalyyseja llomantsista, toimittaneet Seppo Knuuttila, Helmi Järviluoma, Anne Logrén ja Risto Turunen, 50-58. Helsinki: Suomalaisen Kirjallisuuden Seura.

Lähteenmäki, Maria. 2018. "Viipurin julkiset muistomerkit poliittisina tiloina ja muistin paikkoina." Teoksessa Ylirajaiset kaupungit. Sortavala \& Viipuri, toimittanut Miika Raudaskoski, 10-35. Pohjois-Karjalan historiallisen yhdistyksen vuosikirja 18.

Lähteenmäki, Maria ja Jani Karhu (toim.). 2012. Moniääninen Imatra. Imatra: Imatran kaupunki.

Massey, Doreen. 2008. Samanaikainen tila, toimittaneet Mikko Lehtonen, Pekka Rantanen ja Jarno Valkonen, kääntänyt Janne Rovio. Tampere: Vastapaino.

Museovirasto. "Museorakennukset." https://kansallismuseo.fi/fi/seurasaarenulkomuseo/ tutustu-museoon/museorakennukset.

Nora, Pierre. 1978. "Mémoire collective." Teoksessa La nouvelle histoire, toimittaneet Jacques Le Goff, Roger Chartier ja Jacques Revel, 398-401. Pariisi: Retz.

Nora, Pierre. (1992) 1996. "General Introduction: Between Memory and History." Teoksessa Realms of Memory. Rethinking the French Past. Volume 1: Conflicts and Divisions. (Les Lieux de Mémoire), toimittanut Lawrence D. Kritzman, kääntänyt Arthur Goldhammer. New York: Columbia University Press.

NVS Karjalaiset 1. "NVS Karjalaiset - jumppaa Meilahdessa." http://jumppaameilahdessa. blogspot.com.

NVS Karjalaiset 2. Naisvoimisteluseura Karjalaisten Facebook-sivut. Katsottu 5.6.2021. https://www.facebook.com/jumppaameilahdessa/.

Palomäki, Antti. 2011. Juoksuhaudoista jälleenrakennukseen. Siirtoväen ja rintamamiesten asutus-ja asuntokysymyksenjärjestäminen kaupungeissa 1940-1960ja sen käänteentekevä vaikutus asuntopolitiikkaan ja kaupunkirakentamiseen. Akateeminen väitöskirja. Tampere: Tampereen yliopisto.

Paukkunen, Leo. 1989. Siirtokarjalaiset nyky-Suomessa. Jyväskylän yliopiston yhteiskuntapolitiikan laitoksen julkaisuja, A5. Jyväskylä: Jyväskylän yliopisto. 
Paukkunen, Leo. 1997. Siirtokarjalaisten sijoittuminen vuonna 1994. Aineksia tulevaisuuden visioon vuosilta 1940-1996. Jyväskylän yliopiston yhteiskuntapolitiikan työpapereita, n:o 100. Jyväskylä: Jyväskylän yliopisto.

Piela, Ulla. 2001. "Seuraesittelyssä Kalevalaisten Naisten Liitto - valtakunnallinen perinne- ja kulttuurijärjestö." Elore 2001(1). https://journal.fi/elore/article/view/78308/39207.

Piispainkokouksen 9.6.2021 pöytäkirja. Suomen ortodoksinen kirkko. https://ort.fi/sites/ default/files/2021-06/Piispainkokouksen\%20pöytäkirja 421 9.6.2021.pdf.

Puna-Mustat. https://www.pumu.fi.

Pöysä, Jyrki. 2010. "Lähiluku vaeltavana käsitteenä ja tieteidenvälisenä metodina". Teoksessa Vaeltavat metodit, toimittaneet Jyrki Pöysä, Helmi Järviluoma ja Sinikka Vakimo, 331 360. Joensuu: Suomen Kansantietouden Tutkijain Seura.

Ravintola Karelia. http://ravintolakarelia.fi.

Riegl, Aloïs. (1903) 1982. "The Modern Cult of Monuments: Its Character and Its Origin." ("Moderne Denkmalkultus: sein Wesen und seine Entstehung"). Kääntäneet Kurt W. Forster ja Diane Ghirardo. Oppositions 25 (Fall 1982): 21-51.

Saaranen-Kauppinen, Anita \& Anna Puusniekka. 2006. "Havainnointi." KvaliMOTV Menetelmäopetuksen tietovaranto. Tampere:Yhteiskuntatieteellinen tietoarkisto. https:// www.fsd.tuni.fi/menetelmaopetus/kvali/L6 4.html

Saarinen, Eliel ja Kalevalaseura. 1921. "Kalevalatalo. Suomalaisen kulttuuritutkimuksen ahjo ja ohjelma." Kustannusosakeyhtiö Otava.

Sailo, Alpo. 1920."Kalevalatalo." Valvojan Kalevalavihko, helmikuu 1920,77-81. Kalevalaseura. Sihvo, Hannes. 1969. Karjalan löytäjät. Helsinki: Kirjayhtymä.

Sihvo, Pirkko. 2005. "Larin Paraske - taiteilijain modelli museossa." Teoksessa Museon muisti, Ritva Wäreen juhlakirja. Taidehistoriallisia tutkimuksia 31, toimittaneet Anne Aurasmaa, Helena Edgren, Hanna Pirinen, Tuukka Talvio ja Renja Suominen-Kokkonen, 182-194. Helsinki: Taidehistorian Seura.

SKS:n kokouspöytäkirja 3.5.1911. "Suomalaisen Kirjallisuuden Seuran Keskustelemukset v. 1911-1912", teoksessa Suomi - kirjoituksia isänmaallisista aiheista 1.1.1913, toimittanut Suomalaisen Kirjallisuuden Seura. Helsinki: Suomalaisen Kirjallisuuden Seuran Kirjapainon Osakeyhtiö.

Suomen ortodoksinen kirkko. 2021. "Piispainkokouksen päätöksiä 9.6." https://ort.fi/ uutishuone/2021-06-12/piispainkokouksen-paatoksia-96.

Suoninen, Paavo. 2004. Uuden sammon saattajaksi. Karjalatalo 30 vuotta. Helsinki: Karjalan Liitto.

Suoninen, Paavo. 2011. Karjala keskellämme. Pääkaupunkiseudun ja Karjalan vuorovaikutuksesta kautta aikojen. Pääkaupungin Karjalaiset ry.

Suutari, Pekka (toim.). 2013. Karjala-kuvaa rakentamassa. Helsinki:Suomalaisen Kirjallisuuden Seura.

Timonen, Senni (toim.). 1981. Näin lauloi Larin Paraske. Helsinki: Suomalaisen Kirjallisuuden Seura.

Timonen, Senni. 1997. "Larin Paraske (1833-1904)." Kansallisbiografia-verkkojulkaisu. Studia Biographica 4. Helsinki: Suomalaisen Kirjallisuuden Seura. https://kansallisbiografia.fi/ kansallisbiografia/henkilo/3581.

Viipurin Urheilijat. https://www.viipurinurheilijat.fi.

Väisänen, A. O. 1956. "Alpo Sailo ja Kalevalaseura". Teoksessa Kalevalaseuran vuosikirja 36, 255-270. Werner Söderström osakeyhtiö.

Wingate, Jennifer. 2013. Sculpting Doughboys. Memory, Gender, and Taste in America's World War I Memories. Farnham: Routledge. 
Åström, Anna-Maria. 2013."Helsinki-muistotetnologisen historiankirjoituksen lähtökohtana." Teoksessa Muistin kaupunki. Tulkintoja kaupungista muistin ja muistamisen paikkana, toimittaneet Katri Lento ja Pia Olsson, 31-64. Helsinki: Suomalaisen Kirjallisuuden Seura.

FM Anssi Neuvonen on tohtorikoulutettava ja projektitutkija Karjalan tutkimuslaitoksessa Itä-Suomen yliopistossa

FT Maria Lähteenmäki on historian professori ja projektijohtaja Karjalan tutkimuslaitoksessa Itä-Suomen yliopistossa

FT Oona Ilmolahti on projektitutkija Karjalan tutkimuslaitoksessa Itä-Suomen yliopistossa

FT Sinikka Selin on projektitutkija Karjalan tutkimuslaitoksessa Itä-Suomen yliopistossa 